\title{
Atatürk’ün Cenaze Töreni: Yas ve Metanet
}

\section{Tunç BORAN*}

\section{$\ddot{O z e t}$}

Atatürk’ün 10 Kasım 1938 günü ölmesi, Türkiye genelinde büyük bir üzüntü yarattı. Henüz 15 yaşında olan genç Türkiye Cumhuriyeti, kurtarıcı ve kurucu liderini kaybetti. Atatürk'ün kaybı ile genç cumhuriyetin siyasi geleceği de endişe yarattı. Türkiye, Atatürk'ün cenaze töreninde kurucusunu, önderini kaybetmenin yasını tutarken, aynı zamanda metanet içinde cumhuriyetin ayakta kalacağ mesajını vermeye çalışt. Atatürk'ün kaybından sonraki günlerde Türkiye Cumhuriyeti'nin Atatürk'ün yolunda ilerleyeceği mesajı iç ve dış kamuoyuna verildi. Cenaze töreninde, Atatürk'ün kaybından duyulan üzüntü ifade edilirken alınan tedbirlerle metanetli bir duruş sergilendi

Anahtar Kelimeler: Atatürk, Cenaze, Tören, Yas

\section{Atatürk's Funeral Ceremony: Mourning And Fortitude}

\begin{abstract}
When Ataturk died on November 10, 1938, that event has created a great sadness in Turkey. Not yet 15 years old, the young Republic of Turkey has losted her savior and the founding leader. The lost of Atatürk's life has created a concern for the young republic's political future. Turkey, on the one hand, has mourned her founder and the leader; on the other hand, it has tried to convey the message as well as fortitude that the republic will survive. After the loss of Atatürk life, the message was given to internal and external public regarding the Republic of Turkey will follow the path of Ataturk. During the funeral ceremony, it was expressed that the loss of Atatürk was created a great sadness while there have been measures taken to continue a fortitude posture.
\end{abstract}

Key Words: Ataturk, Funeral, Ceremony, Mourning

\footnotetext{
* Çankırı Karatekin Üniversitesi Basın Halkla İlişsiler Uzmanı
} 


\section{Giriş}

1938 yılı Türk siyasi tarihi için trajik bir yıl oldu. Türkiye Cumhuriyeti'nin kurucusu ve ilk cumhurbaşkanı Mustafa Kemal Atatürk, 10 Kasım 1938 günü hayatını kaybetti. İstanbul ve Ankara'da düzenlenen törenlerin ardından Atatürk'ün naaşı, 21 Kasım 1938 günü Etnografya Müzesine konuldu. Atatürk öldüğünde Cumhuriyet henüz 15 yaşındaydı. Atatürk'ün ölümü, cumhuriyetin geleceğiyle ilgili endişeleri de ortaya çıkardı. En büyük endişe kaynağı, Atatürk'ün birleştirici karizmatik liderliğinin destek verdiği cumhuriyetin dayanaklarının bir sarsıntıyla yıkılmasıydı. Türkiye, cenaze töreninde kurucusunu, önderini kaybetmenin üzüntüsünü yaşarken, cumhuriyetin ayakta kalacağı mesajını vermeye çalıştı. Atatürk'ten sonra da Cumhuriyet rejiminin, Kemalist devrimlerin yaşatılacağı Türkiye Cumhuriyetinin aynı yolda sağlam adımlarla devam edeceği mesaj1 iç ve dış kamuoyuna verildi. Atatürk'ün cenaze töreninin süreci ve bu törenin yarattığı yankılar üzerine yapılmış değerli bilgiler içeren bir takım çalışmalar bulunmaktadır. ${ }^{1}$ Bu çalışmada, konu hakkında yeni bir takım bilgi ve belgeler sunularak bilinen bilgiler daha da zenginleştirilecek ve güçlendirilecektir. Bu çalışmada, cenaze töreni boyunca gözlemlenen yas ve üzüntü ile birlikte Atatürk'ün ölümünden kaynaklanan üzüntünün devletin sürekliliğine ve rejime olan inanca yönelik kuşku ve ümitsizliğe dönüşmemesi için alınan tedbirler aktarılacaktır.

\section{Halef Seçimi ve Naaş İşlemleri}

Hükümet, Atatürk'ün ölüm haberini, 10 Kasım 1938 günü öğle saatlerinde resmi bir bültenle açıkladı. Bu bültende hükümet, Atatürk'ün ölümünü iç ve dış kamuoyuna vakur bir şekilde duyuruyordu. Atatürk'ün öldüğü ancak Türkiye Cumhuriyetinin "ölümsüz" olduğu vurgulanıyor, hükümetin görev başında olduğu, otorite boşluğu olmadığ1 mesajı özenle veriliyordu. Bültende, Cumhurbaşkanlığı seçiminin hemen yapılacağı ve seçilecek kişiye hükümetin, milletin bilhassa ordunun destek vereceğinin altı çiziliyordu. Atatürk'ün miras bıraktığı cumhuriyetin titizlikle korunacağ 1 ve

\footnotetext{
${ }^{1}$ Nurcan Toksoy, “Avrupa Gazetelerinde Atatürk’ün Ölümüyle İlgili Olarak Ortaya Çıkan Haber ve Yorumların Türk Basınına Yansıması," Ankara Üniversitesi Türk İnkılap Tarihi Enstitüsü Atatürk Yolu Dergisi, S. 37-38 Mayıs-Kasım 2006, s.141-186; Refik Ahmet Sevengil, “Atatürk’ün Cenaze Törenine Dair Hatıralar,” İnkılâp Gençliği, Y1l:1, S.5, İstanbul, 1952; Seyfullah Esin, “Atatürk’ün Cenaze Merasimine Dair Hatıralar”, Türk Kültürü, Y1l: XIV, S.157 Atatürk Sayısı; Melih Tınal, Atatürk'ün İzmir Ziyaretleri ve Vefatının İzmir'deki Yank1ları, ÇTTAD, VII/16-17, (2008/Bahar-Güz), s.. 19-33; Yasemin Doğaner, "Millet Liderini Uğurluyor," Atatürk Üniversitesi Atatürk Dergisi (Journal of Ataturk), c..IV, Sayı:2, Ocak 2005, s.45-64; Hakan Uzun, "Liderine Ağlayan Bir Ulus: Atatürk'ün Ankara'daki Cenaze Töreni”, Atatürk Yolu, Ankara Üniversitesi Türk İnkılâp Tarihi Enstitüsü Dergisi, S.43, Bahar 2009, s.531-553
} 
Atatürk'ün yolunda devam edileceği bildiriliyordu. Özellikle Türk gençliğinin, Türkiye Cumhuriyetini daima koruyacağ 1 ve Atatürk'ün izinde yürüyeceği vurgulanıyordu. Daha sonra sıklıkla tekrar edilecek olan Atatürk'ün Türk milletinin kalbinde-gönlünde yaşayacağ ilk kez bu metinde ifade ediliyordu. ${ }^{2}$ Hükümetin, Atatürk'ün vefatı ile ilgili açıklaması bu büyük kaybın bildirilmesinden daha çok iç ve dış kamuoyuna herhangi bir otorite boşluğu olmadığı, Türkiye Cumhuriyetinin aynı yolda sağlam adımlarla devam edeceği mesajını vermek üzere kaleme alınmıştı. Metindeki temel kaygı, genç cumhuriyetin bu büyük kaybın acısını yaşamasına rağmen dimdik ayakta olduğunun bilinmesi idi. Bu kayg1, Atatürk'ün ölümünün ardından geçen günleri ve olayları şekillendirdi.

11 Kasım 1938 günü saat 9.30'da CHP Parti Grubu, Cumhurbaşkanı adayını belirlemek için toplandı. Başbakan Celal Bayar, kürsüde kısa bir konuşma yaptı:

"Bugünkü parti toplantımız cumhur reisi için namzet seçmek içindir. Herkes serbestçe istediği bir ismi namzet olarak yazsın. En çok rey alanlar saat 11.00'de yapılacak umumi heyet içtimaında namzet olarak gösterilecektir. ",

CHP Grup Toplantısına 323 milletvekili katıldı. Gizli olarak yapılan oy verme işlemi sonucunda 322 oyun İsmet İnönü için kullanıldığı ortaya çıktı. ${ }^{4}$ Bir oy, Celal Bayar'a verildi. Hikmet Bayur, yıllar sonra Bayar'a çıkan oyu kendisinin verdiğini ifade etti. ${ }^{5}$ CHP Parti Grubu'ndan sonra Cumhurbaşkanlığı seçimi için Büyük Millet Meclisi Genel Kurulu toplandı. Cumhurbaşkanı Vekili ve Meclis Başkanı Abdülhalik Renda, oturumu açtı. Atatürk'ün ölümüne ilişkin tezkere okundu. Atatürk için beş dakikalık saygı duruşunda bulunuldu. Ardından Cumhurbaşkanlığı seçimi için oylamaya geçildi. Oylama sonucunu Meclis Başkanı açıkladı:

"Netice-i arayı arz ediyorum. Reisicumhurun intihabı için 348 arkadaş iştirak etmiştir. 348 reyle ve müttefikan Malatya Mebusu İsmet İnönü Reisicumhur intihap edilmiştir. " 6

\footnotetext{
${ }^{2}$ TBMM Zabit Ceridesi, Devre V, İçtima 4, 14 Kasım 1938, Cilt 27, s..215; Resmi Gazete, Say1: 4059, 10 Kasım 1938; Ulus Gazetesi, 11 Kasım 1938

${ }^{3}$ Asım Us, Asım Us'un Hatıra Notları, Vakit Matbaası, İstanbul, 1966, s. 310; Ş. Süreyya

Aydemir, İkinci Adam, Cilt II, Remzi Kitapevi, İstanbul, 2000, s.23

${ }^{4}$ Kurun Gazetesi, 16 Kasim 1938

${ }^{5}$ Arı, İnan, Tarihe Tanıklık Edenler, Çağdaş Yayınları, İstanbul, 1997, s.322

${ }^{6}$ TBMM Zabıt Ceridesi, Devre 5, İçtima 4, (11 Kasım 1938), Cilt 27, s.16-17; Resmi Gazete, Sayı:4061, 12 Kasım 1938
} 
Seçimin ardından İsmet İnönü, yemin etti ve Türkiye'nin ikinci cumhurbaşkanı oldu.

Türkiye Cumhuriyeti kurucusunun ölümünün hemen ardından ciddi bir sınav vermiş, iktidar çatışması yaşanmadan 24 saat içinde yeni cumhurbaşkanını belirlemişti. Kurucusunu kaybeden Türkiye'de, herhangi bir otorite boşluğu olmadığı mesajı böylelikle verilmiş oldu.

11 Kasım 1938 günü, Ankara'da Cumhurbaşkanlığı seçimleri yapılırken İstanbul Dolmabahçe Sarayında ise naaş, cenaze töreni için hazırlandı. Naaş işlemleri için, Atatürk'ün Müdavi ve Müşavir doktorları, Sağlık Bakanı Dr. Hulusi Alataş ve Sağlık Bakanlığı Müsteşarı Dr. Asım Arar Dolmabahçe Sarayına geldiler. Naaşı, ölüm saatinden 24 saat 10 dakika sonra muayene ettiler, ölümün tüm belirtileri ile gerçekleştiğine karar verdiler. ${ }^{7}$

11 Kasım 1938'de cenaze töreninden önce Atatürk'ün naaşı, tahnit ${ }^{8}$ edildi. Doktorlar, Atatürk'ün "tedfin" (gömme) töreni yapılıncaya kadar naaşının muhafaza edilebilmesi için tahnit yapılmasına karar verdiler. Tahniti, Gülhane Tip Akademisi Patoloji kürsüsünden Prof. Dr. Lütfi Aksu yaptı. Doktorlar, tahnit işlemi için bir rapor düzenlediler.

"Aşağıda imzalarl bulunan tabipler," Atatürk'ün tedfin merasimi yapılıncaya kadar naşın muhafazası için aşağıda yazılı mahlûl ile usulü dairesinde Gülhane Teşrihi Marazi Profesörü Dr. Lütfi Aksu tarafindan tahnit yapılmasına karar verilmiş ve bu tahnit derakep yapılmıştır.

Mahlül:

$\begin{array}{ll}\text { Formalin } & 200 \mathrm{~g} \\ \text { Sublime } & 1 \mathrm{~g} \\ \text { Tuz } & 200 \mathrm{~g} \\ \text { Acide phenique } & 10 \mathrm{~g} \\ \text { Su } & 1000 \mathrm{~g} \text { S.K. için }{ }^{\prime 10}\end{array}$

${ }^{7}$ Utkan Kocatürk. Doğumundan Ölümüne Kadar Kaynakçalı Atatürk Günlüğü Atatürk Kültür Merkezi Yayını, Ankara, 1999, s. 695.

8 Tahnit: Ölüyü bozulmaması için muayyen formül dahilinde ilaçlama işlemi. Ferit Develioğlu, Osmanlıca-Türkçe Ansiklopedik Lugat, Aydın Kitapevi, Ankara, 1990, s.1221

${ }^{9} \mathrm{Bu}$ raporda; Dr. Hulusi Alataş, Dr. Neşet Ömer İrdelp, Dr. Asım Arar, Dr. Akil Muhtar Özden, Dr. M. Kamil Berk, Dr. Süreyya H. Serter, Dr. Abrevaya Marmaralı, Dr. Mim Kemal Öke, Dr. Hayrullah Diker ve ismi okunamayan bir doktor imzaland1. Muhtemelen okunamayan imza aynı gün düzenlenen otopsi raporunda imzası bulunan Prof. Dr. Nihat Reşat Belger'e ait olmalıdır.

10 Devlet Arşivleri Genel Müdürlüğü, Başbakanlığın 8 Ekim 1953 tarih ve 3057 sayılı yazısının eki 
Tahnit, işleminde cesedin iç organları çıkarılmadı, vücut bütünlüğü bozulmadi. Cesede hiç dokunulmadan, damarlara formal solusyonu, asit fenik maddeleri enjekte edilerek tahnit yapıldı. ${ }^{11}$ Prof. Dr. Lütfi Aksu, kullandığı solüsyonu iki küçük şișeye doldurdu, ağzı lehimli șișelerin üzerlerine solüsyon karışımını yazdı. Solüsyon şişelerini, naaşın kolları arasına yerleştirdi. ${ }^{12}$ Tahnitten sonra vücut gazlı bantlarla sarıld1, sonra kefenlendi. ${ }^{13}$ Naaş kahverengi bir muşamba ile sarıldı, kurşun tabut içine kondu ve etrafı ilaçlı talaşlarla doldurulup örtüldü. Kurşun tabut hava almayacak şekilde lehimlendi, sonra bu kurşun tabut, gül ağacından yapılmış başka bir tabutun içine kondu. ${ }^{14}$ Akşam Gazetesinin haberine göre, 13 Kasım 1938 günü dahi naaş yatak odasında bulunuyordu. Tahnit edilen ve tabuta konan naaş, 14 Kasım 1938 günü Dolmabahçe Sarayı Merasim Salonunda hazırlanan katafalka konuldu. ${ }^{15}$

\section{Yas ve Alınan Tedbirler}

Atatürk'ün ölümünün ardından Dolmabahçe Sarayının çatısında bulunan Cumhurbaşkanlığı sancağ 1 yarıya indirildi. ${ }^{16}$ İçişleri Bakanlığ 1 , hükümetin resmi vefat duyurusunu ve doktorların raporunu yayınlamayı beklemeden bayrakların yarıya indirilmesi için genelge yayınladı. ${ }^{17}$ Milli Savunma Bakanlığ 1 da askeri birliklere aynı içerikte bir genelge yayınladı. ${ }^{18}$ Ardından saat 11.25 'ten itibaren bütün bayraklar milli matem sembolü olarak yarıya indirildi. ${ }^{19}$ Bayrakların yarıya indirildiğini fark edenler Atatürk'ün öldüğünü anladılar. O tarihte, İstanbul Kabataş Lisesinde öğrenci olan Prof. Dr. Nezih Eldem, ders sırasında vapurların bayraklarının yarıya indiğini fark ettiklerini, bunun üzerine tüm sınıfın "hüngür hüngür yerlere yatarak, dövünerek ăglamaya başladı̆̆ını" ifade etmektedir. ${ }^{20}$ Türkiye, Atatürk'ün ölümü ile derin bir şoka girdi. O günlerde çekilen fotoğraf ve filmlerde, dehşet dolu bir acının okunduğu yüzler ve ağlayan insanlar görülmektedir. 10 Kasım 1938'de Türkiye'de bulunan Profesör Wolfram Eberhard günlüğüne o acıyı şu şekilde yazmıştır: "Dün öğleden sonra on iki

${ }^{11}$ Ümit Deniz, "Büyük Atanın Tabutu Nasıl Açıldı,” Milliyet Gazetesi, 2 Temmuz 1955, s.3 12 Kamile Şevki Mutlu, "Atatürk’ün Anıt-Kabre Naklinden Bir Hatıra”(14 Mart 1964 Tıp Dergisinden Tıpkı Basım) Bilim ve Teknik Dergisi, Say1:329, Nisan 1995, s. 65

${ }^{13}$ Deniz, a.g.m., s.3

${ }^{14}$ Mutlu, a.g.m., s. 65

${ }^{15}$ Akşam Gazetesi, 14 Kasım 1938, s.9

${ }^{16}$ Nuri Ulusu, Atatürk’ün Yanı Başında, Doğan Kitap, İstanbul, 2009, s.236

${ }^{17}$ Belgelerle Atatürk, Milli Savunma Bakanlığı Yayınları, Ankara, 1999, s.80

${ }^{18}$ Belgelerle Atatürk, s.89-90

${ }^{19}$ Akşam Gazetesi, 10 Kasım 1938

20 Tunç Boran, (Yönetmen) 906 Rakımlı Tepe Belgesel Filmi, Emniyet Genel Müdürlüğü Foto Film Şube Müdürlüğü, 2003 
buçuğa doğru Atatürk'ün öldüğ̈̈nü bildiren haber her yerde işitiliyordu. Muazzam bir şok yaratılmıştı. Ve sessizlik her tarafı kaplamıştı. Çocukların yanı sıra, yetişkin erkekler ve kadınlar ağllyordu. Keder çok yaygındı ve böyle bir şey başka hiçbir ülkede görülmemişti."21 Lord Kinross ise, o gün İstanbul'un acı bir sessizliğe gömüldüğünü belirterek tabloyu şöyle betimlemektedir: "Çocuklar başlarındaki fiyonkları, kurdeleleri çıkardılar. Sokaklarda kadınlar ağlassıyor, Ata'nın siyah tüllere bürünmüş resimleri önünde dua ediyorlardl. ${ }^{, 22} \mathrm{Bu}$ derin, çarpıcı ve samimi üzüntü tüm cenaze töreni boyunca gözlenmektedir.

Ankara Radyosu öğle yayınında ölüm haberini, tüm Türkiye’ye ağlayan bir spikerin sesinden duyurdu. ${ }^{23}$ Ayrıca radyo ölüm haberini, Almanca, Arapça, Bulgarca, Farsça, Fransızca, Hırvatça, İngilizce, İtalyanca, Macarca, Rusça, Sırpça ve Yunanca olmak üzere 11 ayrı dilde dünyaya duyurdu. ${ }^{24}$ Akşam gazetesinin aktardığına göre, Atatürk'ün ölümünün ardından İstanbul'daki tüm sinemalar, tiyatrolar yetkililere müracaat ederek, kapılarına kapalı olduklarını belirten ilanlar astılar. Belediye Başkanlığı da İstanbul Şehir Tiyatrosunun temsillerini tatil etti. 10 Kasım akşamından itibaren eğlence yerleri fasıl ve konserleri iptal etti. Hatta kahvehanelerde kâğıt, tavla, bilardo oyunları dahi oynanmadı. ${ }^{25}$

10 Kasım 1938 günü, İçişleri Bakanlığı, birbiri ardına yayınladığı genelgeleri telgraf yolu askeri ve sivil bürokrasiye ulaştırdı. Kamuoyuna da açıklanan Atatürk'ün ölüm haberi ile ilgili hükümet duyurusu öncelikle gönderildi. ${ }^{26}$ Ardından İçişleri Bakanlığı, başta askeri birlikler olmak üzere tüm bürokrasiden, Atatürk'ün ölümü sonrası kamu düzeninin korunmasını ve gelişebilecek olaylardan merkezin haberdar edilmesini "İntizam ve sükûnun muhafazası için verilen direktifler dairesinde muamele ifası hadise ve cereyanlardan merkezin haberdar edilmesi" ifadesiyle talep etti. ${ }^{27}$ Hükümet Atatürk'ün ölümü sonrası gelişebilecek olaylardan endişe ediyordu. Aslında bu endişeyi, Atatürk'ün ölümünden önce 17 Ekim 1938'de İçişleri Bakanı Şükrü Kaya, gazetecilerle yaptığı toplantıda dile getirmişti:

\footnotetext{
${ }^{21}$ Vamık D. Volkan, Norman Itzkowitz, Ölümsüz Atatürk, Bağlam Yayınları, İstanbul, 1998, s.441

${ }^{22}$ Lord Kınross, Atatürk Bir Milletin Yeniden Doğuşu, Altın Kitaplar Yayınevi, İstanbul, 1994 , s.574

${ }^{23}$ İsmet Bozdağ, Bir Çağın Perde Arkası Kervan Yayınları, İstanbul, 1972, s.212

${ }^{24}$ Ulus Gazetesi, 11 Kasim 1938

${ }^{25}$ Akşam Gazetesi, 11 Kasım 1938

${ }^{26}$ Belgelerle Atatürk, s. 79 ve 81

${ }^{27}$ Belgelerle Atatürk, s. 80 ve 82
} 
"Eğer emri hak vaki olursa tedbir almak lazım. Sizleri onun için çağırdım. Teessür tabii umumidir. Fakat memleketi yeise düşürmemeli. Teessür vesilesiyle nümayişler yapllmasına, toplantılara hatta camilerde mevlit okuma vesaire gibi hallere müsaade etmeyeceğiz. Çünkü iyi niyet ile başlayan bu nevi toplantıların dejenere olduğu görülmüşü̈r.

Atatürk'ün ölümünden bir ay önce hükümet, ölüm sonrası gelişmelerle ile ilgili tedbirleri almıştı. Hükümet, kontrol edilemeyecek kalabalıklardan çekiniyordu. Atatürk'ün cenaze törenine bu güvenlik endişesi damga vurdu.

Hükümet, Atatürk'ün ölümünden önce tedbirler aldı. Hatta cenaze töreni ile ilgili hazırlıklar yapmaya bile başlamıştı. Henüz daha $10 \mathrm{Kasım}$ 1938 tarihinde Kurun Gazetesi, Atatürk'ün Cenazesinin İstanbul'da halk tarafından üç gün boyunca ziyaret edileceğini, ardından cenazenin nakil töreni ile Ankara'ya götürüleceğini, Ankara'daki törenin on güne kadar yapılacağını yazmaktadır. Ayrıca gazete, cenaze töreninin programı için Dışişleri Bakanlığı Genel Sekreteri Numan Menemencioğlu başkanlığında iki komisyon kurulduğunu, komisyonlardan birinin protokol işleri ile meşgul olacağını belirtmektir. ${ }^{29}$ Anlaşılan hükümet, cenaze töreni ile ayrıntıları daha Atatürk'ün ölümünden önce düşünmüştü. Hükümet, ac1 ama mutlak sona hazırlıklı idi.

12 Kasım 1938 günü öğleden önce, Başbakan Bayar başkanlığında yeni hükümet üyeleri, Pembe Köşk'e giderek Cumhurbaşkanı İnönü'ye kendilerine karş1 gösterdiği güvenden ötürü teşekkür ettiler. Aynı gün saat 16.00 'da hükümet, Başbakanlık binasında Cumhurbaşkanı İnönü başkanlığında ilk toplantısını yaptı. Hükümetin ilk toplantısında cenaze töreni ile ilgili hazırlıklar, alınacak önlemler değerlendirildi. Ankara'da düzenlenecek cenaze töreninin 21 Kasım 1938 günü yapılması kararlaştırıldı. ${ }^{30} 23$ Kasım 1938 günü Ramazan Bayramı idi. Gazeteci Asım Us, günlüğüne "Cenaze merasimi Ikkinci Teşrin'in (Kasım) 21'inde olacağına göre, merasim Pazartesi gününe tesadüf edecektir. Bayram ya Salı yahut Çarşamba günü"’31 şeklinde not düştü. Tören programı hazırlanırken bayram tarihine dikkat edilip edilmediği yönünde bilgi bulunmamaktadır. Ancak törenin gerçekleştirildiği 21 Kasım'dan 28 Kasım'a kadar, 23 Kasım'da başlayan Ramazan Bayramı nedeniyle okullar tatil edildi ve törenden iki gün sonra başlayan 1938 yılının Ramazan

${ }^{28}$ Us, a.g.e., s. 300

${ }^{29}$ Kurun Gazetesi, 10 Kasım 1938,

${ }^{30}$ Ulus Gazetesi, 13 Kasım 1938; Akşam Gazetesi, 13 Kasım 1938; Cumhuriyet Gazetesi, 13

Kasım 1938; Aydemir, a.g.e., s.26

${ }^{31}$ Us, a.g.e., s. 318 
Bayramı, Atatürk’ün ölümü nedeniyle tüm ülkede mateme dönüştü. ${ }^{32}$

13 Kasım 1938 günü cenaze töreni ile ilgili ilk genelgeler askeri ve sivil bürokrasiye gönderildi. İçişleri Bakanlığ1 gönderdiği genelgede "tedfin" (gömme) töreninin $21 \mathrm{Kasım} 1938$ günü Ankara'da yapılacağını, tören ile ilgili ayrıntıların daha sonra iletileceğini, vilayetlerin yapacağ bildirdi. Bakanlık, her vilayetten, belediyeden, partiden ve halktan belirlenecek birer kişiden oluşacak üç kişilik bir heyeti 21 Kasım'da düzenlenecek törene göndermelerini, heyetin frak ya da takım elbise giymesini istiyordu. Ayrıca 21 Kasım'1 22 Kasım'a bağlayan gece Atatürk büstü ve heykeli olan kasaba ve şehirlerde büstün veya heykelin çevresinde altı oku temsilen altı meşale yakılmasını, $21 \mathrm{Kas} ı m$ günü saat 16.00'da tüm şehirlerde tören yapılması için hazırlık yapılması isteniyordu. Yine aynı genelgede, 21 Kasım günü dükkan, mağaza ve gazinoların kapanmasının arzu edildiği, ancak bunun mecbur tutulmamasını, bu hususun "telkin" yoluyla sağlanması isteniyordu. Genelge, kaymakam ve valilerin görev başında olmalarını, asayiși sağlamak için hazırlıklı olmaları yönünde uyarı ile sona eriyordu. ${ }^{33}$ Yine 13 Kasım 1938 günü Milli Savunma Bakanlığının askeri birliklere gönderdiği genelge daha ayrıntılıdır. Dışişleri Bakanlığ 1 tarafından hazırlanacak Cenaze töreni programının ve krokisinin basımından sonra gönderileceği, hazırlık yapılabilmesi için programın ana hatları ve görevler sıralanıyordu. 19 Kasım günü Dolmabahçe Sarayından başlayarak 21 Kasım günü Ankara'da yapılacak törene dair ayrıntılar aktarılıyordu. Cenazede tabutu, top arabasina bindirip, indirecek 12 generalin ismi bile belirlenmişti. Genelgede ayrıca Cenaze alayına Birinci Ordu Müfettişi Fahrettin Altay'ın komuta edeceği duyuruluyordu. ${ }^{34}$

13 Kasım 1938 günü öğleden sonra Bakanlar Kurulu Cumhurbaşkanı İnönü'nün evinde bir kez daha topland1. Bakanlar kurulu toplantısında, "Atatürk'ün cenazesinin kendisine layık bir Anitkabir yapılıncaya kadar Etnografya Müzesinde kalması" kararlaştırıldı. ${ }^{35}$ Böylelikle Bakanlar Kurulu, Atatürk için bir Anıtkabir yapılmasına karar verdi. Etnografya Müzesi, "muvakkat kabir" tabiri kullanılarak geçici kabir yeri olarak belirlendi.

Hükümet, Atatürk'ün Cenaze Töreni için yapılacak sarfiyat hakkında kanun tasarısını Türkiye Büyük Millet Meclisine sundu. Kanun tasarısında hükümet, Atatürk'ün naaşının Ankara'ya nakli, Ankara'daki cenaze töreni,

${ }^{32}$ Kurun Gazetesi, 26 Kasim 1938, s.1

${ }^{33}$ Belgelerle Atatürk, s.91

${ }^{34}$ Belgelerle Atatürk, s.129-131

${ }^{35}$ Ulus Gazetesi, 14 Kasım 1938; Akşam Gazetesi, 14 Kasım 1938; Cumhuriyet Gazetesi, 14 Kasım 1938 
buraya gelecek olan askeri kıtaların nakli ve iskân masraflarının yanında, tören için ülkeye gelecek yabancı konukların misafir edilmeleri için yapılacak masraflar için Ziraat Bankası'ndan 500 bin liralık kredi açılmasını istiyordu. Atatürk'ün cenaze programı için yapılacak harcamalara ilişskin kanun, 14 Kasım 1938'de mecliste kabul edildi. ${ }^{36}$ Kanun tasarısının Meclis Genel Kurulunda görüşülmesi, 30 milletvekilinin söz alarak Atatürk'ün kaybından dolayı duydukları üzüntüyü dile getirmeleri için vesile oldu. ${ }^{37}$ Kanun, tahsis edilen paranın nerelere harcanacağı kararını, Bakanlar Kuruluna bırakmıştı. Bakanlar Kurulu, Atatürk'ün cenazesi için yapılan tahsisatın hangi hizmetlere harcandığının belli olmaması nedeniyle 23 madde halinde belirtilmiş hizmetler için yapılan harcamanın kabulünü, 9 Mart 1939'da kararlaştırdı. ${ }^{38}$

Dışişleri Bakanlığ1 Genel Sekreteri Numan Menemencioğlu başkanlığındaki komisyon, 13 Kasım 1938 günü öğleden önce toplandı ve saat 14.00'e kadar çalıştı. İki saat süren bakanlar kurulu toplantısının ardından Dışişleri Bakanı Saraçoğlu ve Başbakan Celal Bayar, Menemencioğlu'nun evine giderek komisyonun aldığı kararları gözden geçirdiler. ${ }^{39}$ Gözden geçirilen program, Dışişleri Bakanlığ 1 Protokol Dairesi tarafından hazırlanmıştı. On dört sayfadan meydana gelen "Atatürk'e Yapılacak Cenaze Törenine Ait Esas Program" da İstanbul ve Ankara'da yapılacak olan törenlerle ilgili olarak yapılması planlanan tüm süreç ayrıntılarıyla belirtilmişti. Tüm tören bu program çerçevesinde yapılmıştır. Program, 16 Kasım 1938 gününden itibaren Dolmabahçe Sarayı Merasim Salonunda Atatürk'ün katafalkının belirlenen protokol sıralamasına göre üç gün boyunca ziyarete açılmasını, 19 Kasım 1938 günü sabah saat 08.30'da Cenazenin Dolmabahçe Sarayından alınmasını, cenaze kortejini, güzergâhı, Yavuz Zırhlısına bindirilişini, İzmit'e varışını, daha sonra tren güzergâhında yapılacakları, Ankara'daki karşılamay1, Meclisten Etnografya Müzesine doğru güzergâhı ve korteji ayrıntıları ile belirliyordu. " "Atatürk'e Yapılacak Cenaze Törenine Ait Esas Program" dönemin gazetelerinde de yayınlandı. ${ }^{41}$ Yarıya indirilen bayrakların ise 21 Kasım 1938 günü saat 24.00'e kadar gönderde kalmasına karar verildi. ${ }^{42}$

${ }^{36}$ Resmi Gazete, Say1: 4063, 15 Kasım 1938

${ }^{37}$ TBMM Zabıt Ceridesi, Devre V, İçtima 4, 14 Kasım 1938, Cilt 27, s..217-239

38 Devlet Arşivleri Genel Müdürlüğü, Cumhuriyet Arşivi, 18.01.02.86.18.16

${ }^{39}$ Ulus Gazetesi, 14 Kasim 1938

40 Hariciye Vekâleti Protokol Dairesi, “Atatürk’e yapılacak Cenaze Törenine Ait Esas Programıdır" Ankara, 1938; Belgelerle Atatürk, s.135-168

${ }^{41}$ Cumhuriyet Gazetesi, 15 Kasım 1938, s.7; Kurun Gazetesi, 15 Kasım 1938, s.8; Ulus Gazetesi, 16 Kasim 1938, s.1-5;

${ }^{42}$ Belgelerle Atatürk, s.93 
21 Kasım 1938 Pazartesi günü Ankara'da ve diğer illerde düzenlenecek tören ile ilgili olarak Cumhuriyet Halk Partisi Genel Sekreterliği parti teşkilatlarına 15 Kasım 1938 günü bir genelge yayınladı. On beş maddeden oluşan genelgede, heykel ve büstlerin ne şekilde süsleneceğinden, söylenecek nutuklara, marşlara ve hatta çiçeklere kadar törende yapılması gereken hususlar sıralandı. ${ }^{43}$ Hükümet de aynı gün cenaze töreni ile ilgili kararname gönderdi. Hükümetin kararnamesi, Cumhuriyet Halk Partisi Genel Sekreterliğinin genelgesine göre daha kısaydı. Hükümetin kararına göre, cenaze töreninin yapılacağ $21 \mathrm{Kasım}$ günü tüm ülkede, resmi daireler ve okullar kapalı olacak, özel müesseselerin de kapanması için valilikler ricada bulunacak, sinema, tiyatro, bar gibi eğlence yerlerin kapalı olmasına dikkat edilecek, devlet memurları 10 Aralık 1938'e kadar davet edildikleri akşam yemeklerine katılmayacak ve akşam yemeği de vermeyeceklerdi. ${ }^{44}$

Tören programı belirlenirken İstanbul ve Ankara'da son hazırlıklar yapılıyordu. Dolmabahçe Sarayı Merasim Salonunda Katafalk hazırlandı. Atatürk'ün tabutunun üstüne Türk bayrağ 1 örtüldü. Tabutun etrafı girland şeklinde güllerle donatıldı. Tabutun çevresine "Altı oku" temsil eden altı meşale konuldu. Yüksek rütbeli altı subay, 16 Kasım sabahından 19 Kasım sabahına kadar nöbet bekledi. "A5 "Altı oku" temsil eden altı meşale, Atatürk'ün cenaze töreninde sıklıkla kullanılan bir sembol oldu. Şehirlerde yapılan törenlerde de altı meşale sembolü kullanıldı. ${ }^{46}$ Dolmabahçe Sarayında bulunan Katafalkta siyah renge yer verilmemişti. Ağırlıklı renk kırmızı idi. Haber Akşam Postası Gazetesi, bunun nedenini lirik bir ifadeyle açıklıyordu: “Türk Milleti, O’nu başında gördügünden beri, yas tutmamaya, yaslı olmamaya söz vermiştir. O'nun hayatını kaybetmesi bile karalar bağlatmamalıdır kendi hayatından önce tuttuğu Aziz Milletine... "47 Matemin sembolü "siyah renk" bilinçli olarak kullanılmamıştır. Cumhuriyet Halk Partisi Genel Sekreterliği vilayetleri gönderdiği yazıyla "toplantı ve merasim esnasında hiçbir siyah işaret" bulundurulmaması yönünde ikaz ediyordu. ${ }^{48}$

\footnotetext{
43 Devlet Arşivleri Genel Müdürlüğü, Cumhuriyet Arşivi 190.01.4.19.45, s.3; Belgelerle Atatürk, s.97-100; Hakan Uzun, "Liderine Ağlayan Bir Ulus: Atatürk'ün Ankara'daki Cenaze Töreni”, Atatürk Yolu, Ankara Üniversitesi Türk İnkılâp Tarihi Enstitüsü Dergisi, S.43, Bahar 2009, s.534

44 Resmi Gazete, Say1: 4064, 16 Kasım 1938; Belgelerle Atatürk, s.95

${ }^{45}$ Ulus Gazetesi, 16 Kasim 1938

${ }^{46}$ Devlet Arşivleri Genel Müdürlügüu, Cumhuriyet Arşivi, 190.01.4.19.45, s.3; Belgelerle Atatürk, s.99

${ }^{47}$ Haber Akşam Postası, 17 Kasım 1938

${ }^{48}$ Devlet Arşivleri Genel Müdürlügü̆, Cumhuriyet Arşivi, 190.01.4.19.45, s.3; Belgelerle Atatürk, s.100
} 
İstanbul'un yanı sıra Ankara'da da katafalk hazırlandı. Türkiye Büyük Millet Meclisinin önünde hazırlanacak katafalk çok daha gösterişli olacaktı. Katafalkı hazırlama görevi, Eğitim Bakanlığı Mimarlık Bürosunda görevli Alman mimar Bruno Taut'a verildi. Zaman kısıtlıdı üstelik Taut hastaydı. Yine de projeyi kısa süre içinde 15 Kasım 1938'de hazırladı. Meclisin giriş aksına yerleştirilen katafalk, $1,5 \mathrm{mx} 1,5 \mathrm{~m}$ boyutunda defne ve meşe dalları sarılmış dört büyük kolonların yanda ve arkada düz kirişlerle birbirine bağlanması ile oluşuyordu. Arka plan açık renkte bir kumaş ile örtülüydü. Tabut için kolonların ortasında yükseltilmiş basamaklı bir podyum yapıldı. Koyu kırmızı renkli podyumun üstüne doğru 10 metre yukarıdan inen bayrak, dramatik kurguyu tamamlıyordu. ${ }^{49}$ Dönemin gazetelerine bakılacak olursa Meclisin önündeki katafalk inşaatı, 16 Kasım 1938 günü başladı ve 20 Kasım 1938 günü düzenlenecek törene yetiştirildi. ${ }^{50}$ Gazeteci-Yazar Altan Öymen anılarında, o dönemde halkın "katafalk" kelimesini ilk kez işittiğini, okulda bu kelimeyi öğretmenin dahi telaffuz edemediğini yazmaktadır. ${ }^{51}$ Katafalk kadar olmasa da cenazeye çelenk göndermek de yeni bir adetti. Reşad Ekrem Koçu'ya göre, bir cenazede yoğun olarak çelenk kullanımının ilk örneği, şair Abdülhak Hamid Tarhan'ın 1937'deki cenazesiydi. ${ }^{52}$ Cenaze alayında bandonun yer almasını ise daha geç tarihlerde görmek mümkündür. Örneğin, 1877 tarihinde Kabuli Paşa'nın cenaze töreninde bandonun bulunduğu bilinmektedir. ${ }^{53}$ Cenaze törenlerinde askeri düzen ve kortej ise Osmanlıda da uygulanan bir yöntemdi. ${ }^{54}$

Tören programı ve hazırlıkları tüm ayrıntıları ile yapılırken güvenlik tedbirleri de üst seviyeye çıkarıldı. Milli Savunma Bakanlığ 15 Kasım 1938 tarihli yazısında, Atatürk'ün cenazesi nedeniyle "halkın teessür ve heyecanindan ve askerin alayda bulunmasindan istifadeye kalkışacak bazı fena kimselerin uygunsuz vaziyet çıkarmalar halinde tedbir almaları" yönünde askeri birlikleri uyardı. Cenaze alayına katılacak askeri birliklerin bir bölüğünde harp fişeği, lüzumlu görülecek birliklerde muharebe fişeği bulundurulması isteniyordu. Milli Savunma Bakanlığının emir yazısında, ayrıca kışlalarda hazır kuvvetlerin bekletilmesini, Merkez komutanlarının

\footnotetext{
${ }^{49}$ Afife Batur, "Katafalk; Ölümün Draması / Duygusal ve Zarif” Atatürk İçin Düşünmek, İstanbul Teknik Üniversitesi Yayını, İstanbul, 1998, s.18

${ }^{50}$ Tan Gazetesi, 17 Kasım 1938; Son Telgraf Gazetesi, 18 Kasım 1938

${ }_{52}^{51}$ Altan Öymen, Bir Dönem Bir Çocuk, Doğan Yayınc1lı, İstanbul, 2003, s.93

${ }^{52}$ Reşad Ekrem Koçu, "Çelenk," İstanbul Ansiklopedisi, Neşriyat Kolektif Şirketi, Cilt:7, İstanbul, 1965, s.3814

53 Edhem Eldem, İstanbul'da Ölüm Osmanlı-İslam Kültüründe Ölüm ve Ritüelleri, Osmanlı Bankası Arşiv ve Araştırma Merkezi Yayınları, İstanbul, 2005, s.66

${ }^{54}$ Eldem, a.g.e., s. 96
} 
istenilen yere topluca kuvvet gönderebilmeleri için gerekli tedbirleri alması talep ediliyordu. ${ }^{55}$

\section{Dolmabahçe İzdihamı}

Tören için güvenlik tedbirleri artırılıyordu. Çünkü Atatürk'ün ölüm haberinin ardından sokaklar hareketlenmişti. 12 Kasım 1938 günü üniversite gençliği, İstanbul Üniversitesi Konferans Salonunda Rektör Cemil Bilsel başkanlığında üçüncü kez toplandı. Atatürk'ün hatırasının anıldığı bu toplantıya Ulus Gazetesinin iddiasına göre, on binden fazla genç katıldı. ${ }^{56}$ Ertesi gün ise, Taksim Meydanında düzenlenen mitingde, Atatürk'ü kaybetmenin verdiği üzüntüyü dile getiren konuşmalar yapıldı. Mitinge katılan on binlerce kişi "Atatürk'ün kendilerine biraktığ Türk İnkılâbını ve Türkiye Cumhuriyetini kanları pahasına koruyacaklarına dair ant içtiler." 57 Mitingde, Taksim Atatürk Anıtına üzerinde "Istanbul Atatürk Üniversitesi Dünya ăglasın Yarattığı tarihe adımız böyle yazılsın” yazılı siyah bir çelenk koyuldu. $^{58}$

15 Kasım 1938 günü bu defa Ankara'da Dil ve Tarih-Coğrafya Fakültesinde toplantı düzenlendi. Toplantıya katılanlar, Atatürk'ü kaybetmenin üzüntüsü ile duygusal konuşmalar yaptılar. Öğretim elemanları ve öğrenciler Türk istiklalini ve cumhuriyetini korumak için ant içtiler. ${ }^{59} 16$ Kasım 1938 günü, Ankara'da üniversite öğrencileri, Ulus Meydanında Zafer Anıtında toplandılar. Anıta çelenk koyuldu ve öğrenciler konuşmalar yaptılar. Törene milletvekilleri ve halk da katıldı. Miting sonrası Başbakan Bayar, üniversite gençliğini temsilen bir kişiyi kabul etti ve takdirlerini ifade etti. Gençler daha sonra yürüyerek Yenişehir'de bulunan anıta ve Kızılay'da bulunan Güven Anıtına çelenk bıraktılar. Ardından yeni cumhurbaşkanı İnönü’ye bağlılıklarını bildiren telgraf gönderdiler. ${ }^{60}$ Hukuk Fakültesinde de benzer bir toplantı düzenlendi. ${ }^{61}$ Üniversite gençliği dışında Ankaralı esnaflarda, 18 Kasım 1938'de Ulus Meydanına giderek Atatürk Anıtına bir çelenk koydular. Esnaf kafilesi, daha sonra Orduevi karşısındaki anıta ve Güven Anıtına da birer çelenk koydu. Tören sırasında Ankara'daki mağaza ve dükkanlar kapalı kaldı. ${ }^{62}$

\footnotetext{
${ }^{55}$ Belgelerle Atatürk, s.94

${ }^{56}$ Ulus Gazetesi, 13 Kasim 1938, s. 1 ve 9

${ }^{57}$ Cumhuriyet Gazetesi, 14 Kasım 1938 s.1; Ulus Gazetesi, 13 Kasım 1938, s.1 ve7-8- 9

${ }^{58}$ Yedigün Dergisi, 22 Kasim 1938, s.10-11

${ }^{59}$ Ulus Gazetesi, 16 Kasim 1938; Tan Gazetesi 16 Kasım 1938

${ }^{60}$ Ulus Gazetesi, 17 Kasım 1938; Akşam Gazetesi 17 Kasım 1938

${ }^{61}$ Ulus Gazetesi, 17 Kasim 1938

${ }^{62}$ Akşam Gazetesi, 19 Kasım 1938
} 
Üniversite gençliğinin Ankara'da düzenlediği miting sonras1 Başbakanın takdirlerini bildirmesi, mitingin ardından yeni cumhurbaşkanına bağlılık mesajının verilmesi, Başbakanın İstanbul'da düzenlenen miting sonras1 Rektör Cemil Bilsel'e teşekkür mesaj1 göndermesi, ${ }^{63}$ bu toplantıların hükümetin kontrolünde gerçekleştiğini düşündürmektedir. Ancak Atatürk'ün ölümüne duyulan üzüntü, her yerde bu kadar rahat organize edilemedi. İstanbullular, Atatürk'ün ölüm haberini aldıktan sonra Dolmabahçe Sarayı önünde birikmeye ve gözyaşları içinde Sarayın çevresini doldurmaya başlamışlardı. ${ }^{64} 16$ Kasım 1938 günü Dolmabahçe Sarayında katafalkın önünden geçişin başlaması ile bu kalabalık daha da arttı.

Dolmabahçe Sarayında önceden belirlenen program çerçevesinde 16 Kasım günü 1938 günü sabah 10.00 'da katafalk ziyareti başladı. Birinci Ordu Müfettişi Orgeneral Fahrettin Altay ve askeri erkân ilk ziyareti gerçekleştirdi. ${ }^{65} 10.15^{\prime}$ de sivil erkân, 10.30 'da üniversite heyeti, onları subaylar, askeri öğrenciler, Cumhuriyet Halk Partisi ve Halkevleri yetkilileri ve izciler takip etti. ${ }^{66}$ Saat 12.00 'den sonra İstanbul halkının ziyareti başladı. Her kesimden insan bulunmaktaydı. Ziyaretçilerden biri de Afganistan'ın Eski Kralı Amanullah Han'dı. O da diğer insanlar gibi ağlıyordu. ${ }^{67}$ Akşama doğru Dolmabahçe Sarayındaki yoğunluk daha da arttı. Cumhuriyet gazetesi, ilk gün sarayın kapısının kapandığı saat 24.00'e kadar ziyaret eden insan sayısın 150.000 olarak verir. ${ }^{68}$ Ulus Gazetesi de 150.000 ziyaretçi olduğunu belirtmektedir. ${ }^{69}$ Cumhuriyet Gazetesi, Dolmabahçe Sarayındaki tabloyu:

"Kadın-erkek, çoluk-çocuk, genç-ihtiyar halk seli... Hıçkırıklar, iniltiler, feryatlar ve dinmez gözyaşları... Fenalaşıp kollarına girilerek salondan çıkarılanlar, üzüntüden bayılanlar..." şeklinde betimlemektedir. ${ }^{70}$

O günlerde İstanbul'da bulunan Alman Arkeolog Dörner, Dolmabahçe Sarayına halkın akını;

"Yüksek demir kapılar ardına kadar açılmış, güller solmuş, fiskiyeler susmuştu; sadece sarayın merdivenlerinden çıkan yüz binlerce insanın ayak sesi duyuluyordu. Haberi duyan yola koyulmuştu. Düzgün klyafetleri içinde memurlar, balıkçılar, hamallar, tüccarlar ve işçiler, yaşlı solgun yüzlü siyah çarşaflı kadınlar arasında kürklü mantolu hanımlar, herkes yas tutuyordu.

${ }^{63}$ Ulus Gazetesi, 16 Kasım 1938

${ }^{64}$ Ulus Gazetesi, 13 Kasim 1938, s.1

${ }^{65}$ Haber Akşam Postası, 17 Kasım 1938,s.8

${ }^{66}$ Cumhuriyet Gazetesi, 17 Kasim 1938

${ }^{67}$ Akșam Gazetesi, 17 Kasım 1938, s.1-7

${ }^{68}$ Cumhuriyet Gazetesi, 17 Kasim 1938

${ }^{69}$ Ulus Gazetesi, 17 Kasim 1938

${ }^{70}$ Cumhuriyet Gazetesi, 17 Kasım 1938 
Tek bir kişi bile sarayın halılarına, resimlere, kristal avizelerine bakmıyordu, tüm bakışlar sadece yüksekte duran, yanında genç subayların bronzdan heykellermiş gibi dimdik nöbet tuttukları tabuta dikilmişti” sözleri ile anlatmaktadır. ${ }^{71}$

Gazeteci Cemal Kutay ise, o günü, "Zerrece protokol, merasim, telkin, hiçbir fani hissin izi yoktu. Bir millet, evet bütün bir millet bir vatandaşı için kendisine başta haysiyet ve istiklal, bütün güzel ve iyi şeyler armağan etmiş, bu uğurda nefsini feda etmişşsefkatli bir babadan öksüz kaldığında nasıl gözyaşı döker? Asrın büyük hadisesine şahit olmayanlar yazl-söz-fotoğrafbeste-tablo hiçbir şeyle anlatmak mümkün değildir bu vefa ve minnet selini..." 72 şeklinde anlatmaktadır.

Kurun Gazetesinden Hakkı Süha Gezgin ise gece geç saatlerde Dolmabahçe Sarayı ile Beşiktaş arasında her tarafin insanlarla dolu olduğunu, kalabalığın sarayın kapısından sığmadığını belirterek saraydaki ziyareti "Daha kapıdan girerken, salonun derin, heybetli sessizliği içine damlamaya başlayan hiçkırıklar, burada bir sağanak halini aldı. Önümde, arkamda sarsilan omuzlar ve yerlerde gözyaşıyla ıslanmış halılar görüyorum. Burada, bereket ki halk hala birleşik bir yığın oluyor. Onları ayakta tutan budur. Nitekim ayrllınca sendelemeler başladı. Düşenler oldu. Polisler koşuştu. Baygınlar, kenarlara çekiliyor. Halinde korkulacak alametler görülenler, cankurtaranlara konuluyor,"73 sözleriyle anlatmaktadır. Tüm protokol kurallarını alt üst eden bir halk seliyle karşı karşıya kalınmıştı. Halkın ziyareti 17 Kasım 1938 günü de devam etti. Ulus Gazetesinden Neşet Atay, ziyaretçi sayısını "Sabahın ilk saatlerinde büyük salonun kapisından dakikada 186 kişi içeri giriyordu. Rakam saat 17'den itibaren sonra 228'e, 23'e doğru 234'e, 23 'ten sonra 250'ye çıkt. Sabahtan ve dünden beri Atatürk'ün önünden kaç kişi geçmiştir dersiniz?" ifadesiyle vermektedir. Atay, gece yarısından sonra Dolmabahçe'de sıra bekleyen 50.000 kişinin olduğunu, kalabalık yüzünden Saraya ulaşamayanların Taksim Atatürk Anıtını çiçeğe gömdüklerini yazmaktadır. ${ }^{74}$

Dolmabahçe Sarayına halkın akın etmesi trajik bir olaya da neden oldu. 17 Kasım 1938 günü saat 20.00'den sonra yüz binden fazla insanın akın etmesi ile meydana gelen izdiham sonucu Dolmabahçe Sarayında çoğunluğu kadın 11 kişi ezilerek öldü. 40'dan fazla yaralı vardı. Gazeteler, olayla ilgili

\footnotetext{
${ }^{71}$ Friedrich Karl Dörner, “Atatürk'e Veda," Mustafa Kemal Atatürk 1881-1938, Çev: Nuran Özyer, Ankara, 1997, s.187

${ }^{72}$ Cemal Kutay, Atatürk’ün Son Günleri, Boğaziçi Yayınları, İstanbul, 1981, s.179

${ }^{73}$ Hakkı Süha Gezgin, "Onun Huzurunda” Kurun Gazetesi, 18 Kasım 1938 s.3

${ }^{74}$ Neşet Atay, "Gece yarısından sonra 50.000 kişi Büyük Ölüyü ziyaret için sıra bekliyordu" Ulus Gazetesi, 18 Kasim 1938, s.7
} 
olarak yalnızca hükümetin gönderdiği resmi tebliği yayınladılar. Bu tebliğin dışında olayla ilgili başka bir haber ya da yorum yayınlayamadılar. Ölenlerin isimleri şöyleydi:

1) “Deniz Yolları Işsetmesi Müdürü Raufi Manyas'ın kızı Bilun (16 yaşıı da)

2) İstiklal Caddesi 236 numarada oturan Anna (58 yaşında)

3) Istiklal Caddesi'nde Yıldırım Apartmaninda oturan Bayan Roya Koşnir,

4) Roya Koşnir'in kızı Bela Koşnir,

5) Bakırköy'den Aşçı Hatice (55 yaşında)

6) Kurtuluş’tan Sütçü Diyamendi (40 yaşında),

7) Topkapı Arpaemini Yokuşu Sokağında oturan Abdülhamit (50 yaşında)

8) Aksaray'da Laleli Caddesinde oturan Bayan Kevser Mehmet (35 yaşıında)

9) Tarlabaşı 19 Numara'da oturan Satenik Ohannes (35 yaşında)

10) Saint Benoit Lisesi Öğrencisi Paul Kuto (15 yaşında)

11) Beyoğlu Lüksemburg Otelinde kalan Belçikalı Leon" "76

17 Kasım 1938 gecesi, Atatürk'ü ziyaret için gelen ve izdihamdan hayatını kaybeden insanlar, farklı etnik kimliklere sahip Türk vatandaşları idi. Her yaştan, her kesimden insan, bu ortak üzüntüyü paylaşıyordu. 6 Aralık 1938 günlü Cumhuriyet Gazetesi, ölenlerin sayısının 13 olduğunu belirtmektedir. O tarihte, hala tedavi altında olan yaralı sayısı ise 6 kişi idi. $^{77}$

Trajik olay, saat 22.30 'da meydana geldi, saat 23.00 'de olay yerine gelen İstanbul Savcısı Hikmet Onat, soruşturmaya başladı. ${ }^{78}$ Savcıllk soruşturmasında, 100 'den fazla kişinin ifadesi alınd. ${ }^{79}$ Adli Tip doktoru Enver Karan otopsi raporunda, ölümlerin solunum yetmezliğinden kaynaklandığını bildirdi. Soruşturma raporunda, tramvayların işlemesinin engellenmemesinin ve saraya girenlerin çıktıktan sonra caddeyi dolaşıp

\footnotetext{
${ }^{75}$ Ulus Gazetesi, 19 Kasım 1938; Akşam Gazetesi, 19 Kasım 1938; Cumhuriyet Gazetesi, 19 Kasim 1938

${ }^{76}$ Haber Akşam Postası, 19 Kasım 1938

${ }^{77}$ Cumhuriyet Gazetesi,6 Aralık 1938

${ }^{78}$ Cumhuriyet Gazetesi, 8 Aralı 1938

${ }^{79}$ Cumhuriyet Gazetesi, 4 Aralık 1938
} 
girmek için bekleyenlerin arasına karıșmalarının halkın yoğun akınının artmasına neden olduğu, bu kalabalığa rağmen güvenlik güçlerinin kordon düzenlemesi yapmadıkları belirtiliyordu. ${ }^{80}$ Savcılık soruşturmasında, Sarayın saat kulesi tarafında bulunan kapının kapatıldıktan sonra tekrar açılmasının halkın şiddetli ve yoğun bir akınına neden olduğu, bu akının izdihama yol açtı̆̆ $\breve{g}_{1}$ bildiriliyordu. ${ }^{81}$ Başka bir iddiaya göre, kalabalığ 1 dağıtma emri alan atlı polislerin hareketi, izdihama yol açmışt. ${ }^{82}$ Savcılık, izdihamın düzeni sağlamakla görevli memurların kusurundan kaynaklandı̆̆ını açıkladı. Mevzuata göre, memurların yargılanabilmesi için idarenin izni gerekiyordu. Savcılık tamamladığ1 soruşturma dosyasını, idari makamlara gönderdi. ${ }^{83}$

Bu olaydan sonra İstanbul Emniyetinde tayin operasyonu başladı. Olay gecesi güvenlik güçlerine komuta eden İstanbul Emniyet Müdür Yardımcısı Kamuran Cuhruk, 26 Kasım 1938 tarihli atama kararnamesiyle Emniyet Genel Müdürlüğ̈̈ Birinci Şube Müdürlüğüne tayin edildi. ${ }^{84}$ İstanbul Emniyet Müdürlüğü Altınc1 Şube Müdürü Faik Abrak da, Mardin Emniyet Müdürlüğüne tayin edildi. ${ }^{85} 1$ Aralık 1938 'de İstanbul Valisi Muhittin Üstündağ, görevden alınarak Bakanlık emrine alındı. İstanbul Emniyet Müdürü Salih Kılıç da Çorum Valiliğine tayin edildi. ${ }^{86} \mathrm{Bu}$ tayinlerin özellikle İstanbul Valisi ve Emniyet Müdürünün tayinlerinin nedeni yalnızca Dolmabahçe Faciası değildi. İnönü'nün Başbakanlıktan alındığı ve halef mücadelesinin sertleştiği dönemde, İstanbul Valisi Üstündağ, İnönü’ye muhalif bir çizgide kalmıştı. İstanbul Valisi ve Emniyet Müdürünün görevden alınması İstanbul'un Ankara'daki yeni İnönü yönetimine bağlanmasını amaçlıyordu. ${ }^{87}$ Ancak Dolmabahçe Faciası da tayinlerin meşru nedenlerinden biriydi. Dönemin gazeteleri, Vali Üstündağ'ın görevden alınmasının nedeni olarak Dolmabahçe izdihamını göstermektedirler. ${ }^{88}$

Savcılık soruşturmasından sonra Dolmabahçe izdihamı ile ilgili idari soruşturma da başlatıldı. 6 Aralık 1938'de olayı soruşturmak için iki mülkiye, bir polis müfettişi görevlendirildi. ${ }^{89}$ Üç müfettiş, olay günü

\footnotetext{
${ }^{80}$ Cumhuriyet Gazetesi, 6 Aralık 1938

${ }^{81}$ Cumhuriyet Gazetesi, 4 Aralı 1938

${ }^{82}$ Cumhuriyet Gazetesi, 14 Aralık 1938

${ }^{83}$ Cumhuriyet Gazetesi, 4 Aralık 1938

${ }^{84}$ Emniyet Genel Müdürlüğü Personel Arşivi, A-1853 Numaralı Özlük Dosyası; Resmi Gazete, Say1:4077, 6 Aralık 1938

${ }^{85}$ Akşam Gazetesi, 13 Aralık 1938, s.3

${ }^{86}$ Resmi Gazete, Sayı:4073, 1 Aralık 1938

87 Cemil Koçak, Türkiye'de Milli Şef Dönemi (1938-1945) 1.Cilt, İletișim Yayınları, İstanbul, 2003, s.183-185

${ }^{88}$ Cumhuriyet Gazetesi, 23 Aralık 1938; Tan Gazetesi, 23 Aralı 1938

${ }^{89}$ Akşam Gazetesi, 7 Aralık 1938; Cumhuriyet Gazetesi, 7 Aralık 1938
} 
Dolmabahçe saray ve meydanında görev yapan polis amir ve memurlarından 50 kişinin $^{90}$ Beşiktaş Emniyet Amiri Lütfi'nin, ${ }^{91}$ Beşiktaş Karakolunda çalışan polis memurları ve amirlerinin, ${ }^{92}$ karakollardan saraya yardımcı kuvvet olarak gelen polis memurlarını ${ }^{93}$ saray memur ve hademelerinin, ayrıca olayın şahitlerinin $^{94}$ ifadelerini aldılar. Müfettişler, olayda hayatını kaybedenlerin aileleri ile de görüştüler. ${ }^{95}$ İstanbul Emniyet Müdürlüğü eski Altıncı Şube Müdürü Faik Abrak ${ }^{96}$ ve İstanbul Emniyet Müdürlüğü Üçüncü Şube Müdürü Mehmet Tanyeri ifade verdi. ${ }^{97}$ Eski İstanbul Emniyet Müdürü, Çorum Valisi Salih Kılıç, müfettişler tarafindan iki defa dinlendi ${ }^{98}$ Kılıç, verdiği ifadede olay gecesi güvenlik güçlerine kendisinin değil İstanbul Emniyet Müdür Yardımcısı Kamuran Cuhruk'un emir verdiğini, kendisinin sorumlu olmadığını söyledi. Bu ifade üzerine müfettişler, iki saat boyunca İstanbul Eski Emniyet Müdür Yardımcısı Kamuran Cuhruk'un ifadesini aldılar. ${ }^{99}$ Dolmabahçe izdihamının yaşandı ğı gece, İstanbul Emniyet Müdürü ve yardımcısı, olayın sorumluluğu konusunda İstanbul Emniyet Müdürlüğü binasında şube müdürlerinin önünde tartışmışlardı. Müfettişler, olay mahallinde yeterli güvenlik gücünün bulundurulmadığını ve görevde bulunan polis memurlarının sabah saat 08.00 'den gece 24.00 'e kadar aralıksız nöbette tutulduklarını saptadılar. ${ }^{100}$

Müfettişler, yaklaşık bir ay çalışarak Dolmabahçe Faciası soruşturmasını tamamladılar. ${ }^{101}$ İdari soruşturma sonucunda müfettişler, dönemin İstanbul Valisi Muhittin Üstündağ, İstanbul Emniyet Müdürü Salih Kılıç, Beyoğlu Kaymakamı Daniş Yurdakul, İstanbul Emniyet Müdür Yardımcısı Kamuran Cuhruk ve bazı idari yöneticilerin görevlerini ihmal ettikleri sonucuna ulaştılar. Soruşturma dosyası adli muhakeme kararı için Danıştay'a gönderildi ${ }^{102}$ Danıştay, Dolmabahçe olayından ötürü dönemin İstanbul Emniyet Müdürü Salih Kılıç'ın ve İstanbul Emniyet Müdür Yardımcısı Kamuran Cuhruk'un muhakemesine, Vali Muhittin Üstündağ ve

\footnotetext{
${ }^{90}$ Akşam Gazetesi, 9 Aralık 1938

${ }^{91}$ Cumhuriyet Gazetesi, 7 Aralık 1938

${ }^{92}$ Akșam Gazetesi, 18 Aralık 1938

${ }^{93}$ Akşam Gazetesi, 14 Aralık 1938

${ }^{94}$ Akşam Gazetesi, 11 Aralık 1938

${ }^{95}$ Akşam Gazetesi, 24 Aralık 1938; Cumhuriyet Gazetesi, 22 Aralık 1938

${ }^{96}$ Akşam Gazetesi, 9 Aralık 1938

${ }^{97}$ Cumhuriyet Gazetesi, 10 Aralik 1938

${ }^{98}$ Akşam Gazetesi, 9 Aralık 1938

${ }^{99}$ Akșam Gazetesi, 15 Aralık 1938

${ }^{100}$ Cumhuriyet Gazetesi, 24 Aralı 1938

${ }^{101}$ Cumhuriyet Gazetesi, 30 Aralı 1938

${ }^{102}$ Akşam Gazetesi, 3 Ocak 1939
} 
diğer yöneticilerin men-i muhakemesine karar verdi. ${ }^{103} 17$ Kasım 1938 gecesi, Dolmabahçe Sarayında izdihamdan 11 kişinin hayatını kaybettiği olaydan dönemin İstanbul Emniyet Müdürü Salih Kılıç ve Emniyet Müdür Yardımcisı Kamuran Cuhruk sorumlu bulundu ve yargilanmalarına karar verildi. Danıştay, Salih Kılıç ve Kamuran Cuhruk'un Kocaeli'nde yargılanmasına hükmetti. Tahkikat evrakı ve muhakeme kararı Kocaeli'ne gönderildi. ${ }^{104}$ Salih Kılıç ve Kamuran Cuhruk, Kocaeli Ağır Ceza Mahkemesinde Dolmabahçe'deki izdihamdan dolayı vefata sebebiyet davasında yargılandılar. Duruşmalar sırasında dönemin Altıncı Şube Müdürü Faik Abrak da şahit olarak dinlendi. Faik Abrak, ifadesinde izdihama halkın heyecanının neden olduğunu, alınan tedbirlerde bir noksan olmadığını ve Salih Kılıç ve Kamuran Cuhruk'un tedbirsizlik ve ihmal göstermediklerini söyledi. Faik Abrak, meslektaşları ve eski amirleri lehinde şahitlik yaptı. ${ }^{105}$ Salih Kılıç'ın yargılama sonucuna ulaşılamamıştır. Ancak Salih Kılıç'ın memuriyet hayatına devam etmesi, 19 Haziran 1948 yılında Ordu Valiliğine atamasının yapılmas ${ }^{106}$ ve emekliye ayrıldığ 1 tarih olan 18 Haziran 1951 yılına kadar Ordu Valiliği yapmış olması ${ }^{107}$ yargılama sonucunda "ă̆ır bir ceza" almadığını göstermektedir. Dolmabahçe Faciasından dolayı memurlar, ceza almaz iken hükümet cenaze töreninde görev alan memurlara takdirname verilmesini kararlaştırdı. Milli Savunma, Dışişleri ve İçişleri Bakanlıkları, Başbakanlığa Atatürk'ün cenaze töreninde görev yapan takdirname alacak memurların listesini gönderdiler. Takdirname listesinde, Dolmabahçe Faciası soruşturmasında ifadesi alınan Emniyet Müdürü Faik Abrak'ın ve Mehmet Tanyeri'nin ismi de yer aliyordu. ${ }^{108}$

17 Kasım 1938'de Dolmabahçe'de meydana gelen izdiham, dönemin basının incelenmesi açısından da önemlidir. İzdihamın meydana geldiği günlerde basın, olayla ilgili olarak yetkililerden gelen resmi tebliği yayınlamakla yetindi. ${ }^{109}$ On bir kişinin öldüğü bir haberle ilgili olarak detaylı bilgiye ve yoruma yer vermemeleri konusunda dönemin gazeteleri uyarılmış olmalıdır. İstanbul Valisi Muhittin Üstündağ ve İstanbul Emniyet Müdürü Salih Kılıç'ın 1 Aralık 1938'de görevden alınmalarından sonra basının olaya ilgisi arttı. İzdiham ile ilgili savcılık ve idari soruşturma basın tarafından

${ }^{103}$ Tan Gazetesi, 5 Temmuz 1939

${ }^{104}$ Ulus Gazetesi, 17 Ekim 1939

${ }^{105}$ Ulus Gazetesi, 30 Kasim 1939

${ }^{106}$ Devlet Arşivleri Genel Müdürlüğü, Cumhuriyet Arşivi, 30..18.12.116.42..7

${ }^{107}$ Devlet Arşivleri Genel Müdürlüğü, Cumhuriyet Arşivi, 30..18.12.126.56..1

${ }^{108}$ Devlet Arşivleri Genel Müdürlüğü, Cumhuriyet Arşivi, 030-0-010-000-000-1-4-13

${ }^{109}$ Ulus Gazetesi, 19 Kasım 1938; Akşam Gazetesi, 19 Kasım 1938; Cumhuriyet Gazetesi, 19 Kasım 1938 
izlendi ve detayları ile aktarıldı. Görevden alınan İstanbul Valisi Üstündağ ve ekibi hakkında açılan Otobüs, Asri Mezarlık ve Sürpagop Mezarlık davaları da aynı şekilde basın tarafından yoğun ve detaylı bir şekilde takip edildi. Koçak, basının Eski İstanbul Valisi ve ekibi hakkındaki yolsuzluk ve usulsüzlük davalarına olan yoğun ilgisini, yeni İnönü yönetiminin yönlendirdiğini, desteklediğini ifade etmektedir. ${ }^{110}$ Basının Dolmabahçe izdihamı ile ilgili haberlerini bu açıdan da değerlendirmek mümkündür.

Dolmabahçe Sarayında meydana gelen izdiham, 19 Kasım 1938 günü Cumhuriyet Halk Partisi Meclis Grubunda da görüşüldü. İzdiham sonucu ölen insanların kaybından dolayı üzüntü dile getirildi. Güvenlik önlemlerinin arttırıldığı belirtilerek halktan daha dikkatli olmaları istendi. ${ }^{111}$ Dolmabahçe izdihamı, cenaze töreni için alınan güvenlik tedbirlerini daha da sıkılaştırdı. Ankara'daki törende güvenlik önlemleri daha yoğun oldu.

\section{Cenaze Namazı}

Dolmabahçe Sarayında meydana gelen izdihama rağmen 18 Kasım 1938 günü de katafalk ziyaretine devam edildi. Ulus Gazetesine göre, gece yarısından sonra saraya giremeyen halk evine dönmedi, 10.000 kişi geceyi sokakta geçirdi. Katafalkın önünden İstanbulluların geçişi tüm gün sürdü ve 18 Kasım 1938 günü saat 24.00'de üç gün süren ziyaret sona erdirildi. Aynı gün Başbakan Celal Bayar, saat 12.00'de Ankara'dan İstanbul'a geldi. Cumhurbaşkanı İnönü, İstanbul'a gelmedi, Ankara'da kalmayı tercih etti. Bayar, cenazenin İstanbul'dan Ankara'ya nakil töreni için gelmişti. Başbakan, Dolmabahçe Sarayında katafalkı ziyaret etti. ${ }^{112}$

19 Kasım 1938 günü, İstanbul'dan Ankara'ya Atatürk'ün cenazesinin nakil töreni yapılacaktı. Atatürk'ün naaşının yer aldığı tabut, 19 Kasım günü Dolmabahçe'den çıkarılmadan önce cenaze namazı kılındı. Ancak öncesinde cenaze namazı konusunda bir tartışma yaşandı. Hükümet, camide kılınacak cenaze namazının amacından saptırılabileceğini düşünüyor, dini olayların meydana gelmesinden çekiniyordu. Cenaze namazı tartışmasını, cenaze töreninin güvenliğinden sorumlu olan Orgeneral Fahrettin Altay, şöyle anlatmaktadır:

"Programa göre cenaze İstanbul'dan alınacak, Ankara'ya gönderilecekti. Ankara'ya sordum: 'Cenaze namazı Istanbul'da mi yoksa Ankara'da mı kılınacak?' Akşama kadar bir cevap alamadığım için akşam

\footnotetext{
${ }^{110}$ Cemil Koçak, Türkiye’de Milli Şef Dönemi (1938-1945) 1.Cilt, İletişim Yayınları, İstanbul, 2003, s.186-189

${ }^{111}$ Ulus Gazetesi, 20 Kasim 1938

${ }^{112}$ Ulus Gazetesi, 19 Kasim 1938
} 
tekrar sordurdum. 'Yarın sabah Başbakan Celal Bey, oraya gelecek. Görüşürsünüz' cevabını aldığım vakit hayret ettim. Acaba bunda görüşecek ne vardı? Ertesi sabah Bayar, geldi. Dolmabahçe Sarayında görüştük. Cenaze namazı konusunda düsünceleri, Istanbul'da veya Ankara'da cenaze namazı esnasında bazı dini olaylar meydana gelmesinden laik hükümet çekiniyordu. Kendilerine ben: 'Bir şey olacağını sanmam. Bu gelenek olmuşs bir dini vecibedir., namaz kllinmazsa bu millet elli sene sonra, yüz sene sonra mezardan çıkarır, namazını kılar. Onun için namaz kılınmayacaksa, beni vazifemden affetmenizi rica ederim' dedim" "113

Orgeneral Fahrettin Altay ile cenaze namazı konusundaki görüşmeyi Bayar ise: "Benim babadan kalma hocalı̆̆ım da var ya... Cenaze namazının camide kllınmaması halinde istifa edeceğini söyleyen Altay'a, bunun farz değil farz-ı kifaye olduğunu anlattım. Cenaze kaldırılmadan önce namazın kılınmasının şeriata aykırı olmadiğını, yani dini hükümlere aykırılık bulunmadığını izah ettim. Böylece Dolmabahçe Sarayında Vakıflar Müdürü tarafindan Atatürk'ün cenaze namazı kıldırıldı." 114

Cemal Kutay'ın aktardığına göre, cenaze namazının kılınması için naaşın bir camiye götürülmesinin dinen şart olup olmadığı konusunda "Bayar'ın babadan kalma hocalık" bilgisi ile yetinilmediği anlaşılmaktadır. Kutay, konunun İstanbul Üniversitesi Öğretim Üyesi Prof. Mehmet Şerafettin Yaltkaya'dan sorulduğunu, Yaltkaya'nın böyle şer'i bir zorunluluk olmadığını, fakat bir kere de Diyanet İşler Başkanı Mehmet Rıfat Börekçi'ye sorulmasını istediğini, Diyanet İşleri Başkanı Rıfat Börekçi’nin de Yaltkaya'nın düşüncesini paylaşarak, "O'nun cenaze namazı, tertemiz hale getirdiği bütün vatanda, bu farizanın yerine getirilebileceği her yerde kllınabilir" dediğini yazmaktadır. ${ }^{115}$

18 Kasım günü Dolmabahçe Sarayına gelen Bayar'1, cenaze namazı konusunu görüşmek için bekleyen yalnızca Fahrettin Altay değildi. Gazeteci Cemal Kutay'a göre Bayar, Atatürk'ün kız kardeşi Makbule Atadan'ın cenaze namazı konusundaki sorusu ile karşılaştı:

"Makbule Hanımefendi, hole çıktı. Yüksek sesle 'Bayar, cenaze namazı kılınmayacakmış' diye ağladı. Bunun üzerine Celal Bayar merdivenlerden çıtı. Yüksek sesle duyurulurcasına 'Atatürk'ün cenaze namazı kılınacaktır. Ananelerimiz, adetlerimiz neyse sonuna kadar yerine getirilecektir. Müsterih

\footnotetext{
${ }^{113}$ Fahrettin Altay, On Yıl Savaş ve Sonrası, İnsel Yayınevi, İstanbul, 1970, s.501-502

${ }^{114}$ Mehmet Barlas, "Celal Bayar'1n Anıları," Günaydın Gazetesi, 9 Nisan 1976, s.7

${ }^{115}$ Cemal Kutay, a.g.e., s. 190
} 
olun rahat edin, üzülmenize hiçbir sebep yoktur' gibi birkaç cümle kullandı." 116

Münir Hayri Egeli de Cemal Kutay'ın aktardığı olayı doğrulamaktadır. Egeli, Dolmabahçe Sarayında Cemal Kutay ve birkaç gazetecinin de bulunduğu sırada, Makbule Atadan ile Bayar arasında cenaze namazı konusunda görüşme olduğunu, Bayar'ın 'Elbette Cenaze Namazı kllınacaktır" dediğini aktarmaktadır. ${ }^{117}$

Atatürk'ün cenaze namazının bir camide k1lınmasının, güvenlik endişesine neden olduğu görülmektedir. Camide kılınacak namazın denetlenemeyen yoğun bir kalabalığa neden olacağı düşünülüyordu. Anlaşılan bu nedenle, cenaze namazının cami yerine Dolmabahçe Sarayının Merasim Salonunda kılınmasına karar verildi. Ancak tek neden güvenlik endişesi değildi. Laik devletin resmi cenaze töreninde, cenaze namazı gibi dini bir ritüelin nasıl uygulanacağ 1 sorunu ile karşılaşıldı. Celal Bayar, cenaze namazının kılınmaması önerisini "laikliği yobazca yorumlayanların" düşüncesi olarak nitelemektedir. ${ }^{118}$ Gazeteci Asım Us da, cenaze namazı konusunda yaşanan tartışmayı günlüğüne şu şekilde not etti:

"Atatürk din hususunda (laik) idi, yani devlet işleri ile din ve vicdan işlerini tamamıyla birbirinden ayırmış̧t. Atatürk (laik) olduğu için cenaze namazını da, resmi merasim dışında olarak kendi ailesi kıldıracaktır. Hükümet'in bu husus ile alakası bulunmayacaktır.",119

Anadolu Ajans1, 19 Kasım 1938 günlü bülteninde cenaze namazının "Atatürk'ün ailesinin talebi ile kılındı̆̆ını" belirtmeye ihtiyaç duydu ${ }^{120}$ Behçet Kemal Çağlar'ın notlarına göre, 19 Kasım 1938 günü saat 08.10'da, salonun ortasındaki büyük avizenin altına konmuş iki masa üzerine tabut yerleştirildi; ve cenaze namazına başland.. ${ }^{121}$ İmamlık görevini Şerafettin Yaltkaya, müezzinlikleri de Hafız Yaşar ve Hafız İsmail yaptılar. ${ }^{122}$ Tekbir, Türkçe verildi ${ }^{123}$

Atatürk'ün cenazesi, aynı zamanda devletin resmi cenaze töreni ritüelinin oluştuğu bir uygulama oldu. İngiltere'nin Ankara Büyükelçisi Sir

\footnotetext{
${ }^{116}$ Boran, (Yönetmen) a.g.f.

${ }^{117}$ Münir Hayri Egeli, Atatürk’ten Bilinmeyen Hatıralar, Yaşaroğlu Kitapçılık, İstanbul, 1959, s. 127

${ }^{118}$ Barlas, a.g.m.. s. 7

${ }^{119}$ Us, a.g.e., s. 322

${ }^{120}$ Ayın Tarihi Dergisi, Say1 60 Mükerrer, 1-30 Kasım 1938, s.44

${ }^{121}$ Behçet Kemal Çağlar, Dolmabahçe'den Anıtkabir'e, Sel Yayınları, İstanbul, 1955, s.7

${ }^{122}$ Cumhuriyet Gazetesi, 20 Kasim 1938; Ulus Gazetesi, 20 Kasim 1938

${ }^{123}$ Ayın Tarihi Dergisi, Say1 60 Mükerrer, 1-30 Kasım 1938, s.44
} 
Percy Loraine de İngiliz Dışişleri Bakanlığına gönderdiği raporda, cenaze töreninin bu yönüne dikkat çekmektedir:

“Türkiye'de Batı anlamında devlet cenaze töreni geleneği yoktur; fakat Türkiye Cumhuriyetinin kurucusu için oldukça parlak bir tören yapılmayacă̆l akıldan geçmezdi. Bilakis Türk Hükümeti, bu günü en ciddi ve en parlak bir gün haline getirmek için elden gelen gayreti esirgemedi. Batı'da uygulanan usul, dini kısımları adapte edilerek veya değiştirilerek büyük ölçüde tatbik edildi. En titiz arajmanlar, pek ala bir şekilde yerine getirildi ve törenler münasip ve layı bir şekilde yapıldı." ${ }^{2124}$

Atatürk'ten sonra hayatını kaybeden devlet büyüklerinin cenaze törenlerinde devlet töreni geleneği oluştu. $\mathrm{Bu}$ geleneğin başlangıcı Atatürk'ün cenaze töreni oldu.

\section{İstanbul'dan Ankara'ya Nakil Töreni}

Cenaze namazının kılınmasından sonra naaşın bulunduğu tabut, 19 Kasım 1938 günü 08.21'de, Dolmabahçe'den çıkarılarak top arabasına konuldu. Resmi nakil törenini oluşturan cenaze korteji saat 08.59 'da hareket etti. Kortej, tramvay yolunu takiben Tophane, Karaköy, köprü yolu ile Eminönü Meydanı, Bahçekapı, Sirkeci ve Salkımsöğüt üzerinden Gülhane Park1 ve park içindeki yolu takiben Sarayburnu'na 12.26 ' da ulaşt. ${ }^{125}$

Atatürk'ün cenazesinin geçeceği yolları İstanbullular, doldurmuştu. Sadece yollar değil, Marmara Denizinde de cenaze alayını izlemek için kayıklar ve motorlardaki insanlar vardı Gazetelere göre, Atatürk'ün top arabasındaki tabutunu gören halk gözyaşlarına boğuldu. Pek çok insan feryat ederken, pek çoğu da bayılmaktaydı. ${ }^{126}$ Dolmabahçe'den Sarayburnu'na kadar bütün caddeler, caddelere inen bütün yollar, yamaçlar, binalar, damalar, cami kubbeleri, minareler insanlarla doluydu. Ulus gazetesi, güvenlik endişesi nedeniyle geceden itibaren tüm vapur seferleri kaldırılmış, tramvaylar durdurulmuş olmasına rağmen saat 07.00'den itibaren güzergâhı görebilecek her noktanın insanlarla dolduğunu belirtmektedir. ${ }^{127}$

Camilerin minarelerine çıkanların içinde gazeteci Zekeriya Sertel'de vard1. Sertel, anılarında o günü, şöyle anlatıyordu.

\footnotetext{
${ }^{124}$ Salahi Sonyel, "İngiliz Belgelerinin Işı̆̆̆ Altında Atatürk'ün Son Günleri," Belleten Cilt XXV Sayı 140, Türk Tarih Kurumu, Ankara, Ekim 1971, s. 571

${ }^{125}$ Çağlar, a.g.e., s.7-9

${ }^{126}$ Cumhuriyet Gazetesi, 20 Kasım 1938; Akşam Gazetesi, 19 Kasım 1938

${ }^{127}$ Ulus Gazetesi, 20 Kasim 1938
} 
"Cenazenin kaldırllacağı gün, bütün şehir halkı erkenden sokaklara dökülmüşü. Dolmabahçe'den Sultanahmet'e giden yol daha sabahtan Atatürk'e son saygl ödevini yapmak isteyen insanlarla dolmuştu. Eşimle ben cenaze alayın daha iyi görebilmek için Yeni Cami minarelerinden birinin birinci şerefesine çıkmıştık. Karaköy'e kadar her yer insanla doluydu. Nihayet köprünün Karaköy ucundan cenaze alayı göründü. En önde elinde siyah şapkasıyla başı açık yürüyen Celal Bayar, arkasından top arabasında Atatürk'ün tabutu. Arkasindan tekbir sesleri, matem havasi çalan askeri muzika. Ve sonra gençler, ögrenciler ve bir karabulut yığını halk yığınları... Aşă̆ıdan ilahi sesleri ve hıçkırıklar yükseliyordu. "128

Cenaze törenlerini izleyenler içinde yazar Reşat Nuri Güntekin'de vard1. Reşat Nuri Güntekin, kortejde yer alan Başbakan Celal Bayar'ın ağladığını yazmaktadır:

“Alay'ı Fındıkl taraflarında bir sokak ăgzından, kucaklarına çocuklarını yüklenmiş yoksul kıyafetli birkaç kadın ve erkek, konuşmalarından Ata'nın eski silah arkadaşları olduklarını anladığım iki yaşlı gazi ve temiz elbiseleri olmadiğ için okullarının taburuna girememiş dört beş çocukla beraber seyrediyordum. Top arabasını takip eden kesif guruplar arasındaki yedişer sekizer metrelik muntazam boşluklardan birinin ortasında bir aralık tek bir insan görüldü. Üzerinde herhalde resmi kıyafet, frak ve silindir bulunması lazımdl. Fakat nedense bu fark edilmiyor. O Cihangir ve Findıkl tepelerinden inen dizi dizi sokakları doldurmuş kalabalıkların içinden, dalgınlıkla bu boşluğa yürüyüvermiş rasgele bir insana benziyordu. Gözlüklerinin içi yaşla dolmuştu. Vücudu hafif̧̧e öne eğilmiş, çehresi yorgun yavaş yavaş ağlayarak yürüyordu. Bu Başvekilimiz Celal Bayar'di,"'129

Cenaze törenini dakika dakika not eden Behçet Kemal Çağlar'da durumu şu şekilde betimlemektedir.

"Yolun kenarındaki setler insanlarla dolu. Hiçkırıtan arabanın ve ayakların sesleri duyulmaz oldu. Bütün millet ağllyor sözü ilk defa benzetme olmaktan çıkmış. Bütün yollar adeta bedenden bir dağ, baştan bir nehir. Findıklı'dan ayrildık. Kenarlarda sıralanmış mektepler, sokaklar dolmuş, halk cadde kenarındaki ev ve dükkânları hınca hınç doldurmuş, kalabalık, ağaç üstlerine ve minare şerefelerine tırmanmış kimseler dövüne dövüne, hıçkıra hıçkıra ağlıyorlar." 130

${ }^{128}$ Zekeriya Sertel, Hatırladıklarım, Gözlem Yayınları, İstanbul, 1977, s.217

${ }^{129}$ Reşat Nuri Güntekin, “Celal Bayar'ın Gözyaşları,” Tan Gazetesi, 20 Kasım 1938

${ }^{130}$ Çağlar, a.g.e., s. 8 
Kortej, Tophane ve Fındıklı arasından geçerken feryat ve çı̆̆lık seslerinin çok artmasından dolayı kortejin güvenliğinden sorumlu Fahrettin Altay, tabutu taşıyan top arabasını geçici süre durdurma gereğini hissetti. Cenaze kortejinin geçeceği yolları gören binalarda pencereler, cenaze kortejini izlemek isteyenlere kiraya verildi. ${ }^{131}$

Cenaze kortejinin geçtiği sırada kalabalık ve izdihamdan bazı olaylar da oldu. Boğazkesen Caddesinden taşan ve cenaze kortejinin geçeceği caddeyi kaplayan halkı durdurabilmek için polis itfaiyeden yardım istemiş, su sıkarak caddeyi kaplayan kalabalığı dağıttı. ${ }^{132}$ Gülhane Parkının kapısında ise naaşın Sarayburnu'nda Zafer Torpidosu'na naklini görmek isteyenler akın etti. Yer darlığı yüzünden oluşan izdihamı engellemek için ordu mensupları kalabalığı geri itmek için silah dipçiklerini kullandılar. İngiliz Büyükelçiliğinin raporuna göre, olay sırasında pek çok kişi yaralandı ancak dönemin Türk basınında bu haber yayınlanmadı. ${ }^{133}$ Ama daha vahimi cenaze kortejini izleyenlerin doldurduğu bir bina çöktü. Eminönü’nde eski bir binanın çökmesiyle 14 kişi yaraland. ${ }^{134}$

İstanbul'daki cenaze törenine katılanların sayısını bir gazete 600.000 kişi olduğunu iddia etmektedir. ${ }^{135} \mathrm{Bu}$ rakam, o y1llarda tahmini 750.000 olan İstanbul nüfusuna yaklaşmaktadır. Törene katılanların sayısının tam olarak bilinmesi mümkün değildir ancak kesin olan 19 Kasım 1938, İstanbul'un tarihi günlerinden birisi olmuştur.

Atatürk'ün naaşı Sarayburnu'ndan, Zafer Torpidosu'na, oradan da naaşı İzmit'e götürecek olan Yavuz zırhlısına konuldu. Atatürk'ün naaşının Yavuz'a konulması sırasında ona yabancı devletlere ait savaş gemileri ve töreni denizden takip etmek isteyenler için belirlenmiş vapurlar da eşlik etmiştir. Yavuz zırhlısı, Atatürk'ün cenazesini aldıktan sonra, arkasında Hamidiye, Zafer, Tınaztepe ve iki denizaltı gemisi ile Savarona, sancağında İngiliz dretnotu, bunu takiben Sovyet, Alman, Fransız, Yunan, Romen savaş gemileri, üstünde uçak filoları olduğu halde Marmara açıklarına doğru ilerlemeye başladı. ${ }^{136}$ Atatürk'ün cenaze töreni için yabancı savaş gemileri de gelmişti. İngiltere'den Malaya, Sovyetler Birliği'nden Moskova, Romanya'dan Regina Marina, Fransa'dan Emile Bertin, Almanya'dan

\footnotetext{
${ }^{131}$ Cemal Kutay. "Büyük Ölünün Tabutu İstanbul'dan Ayrılırken.” Ulus, 21, 11, 1938, s.5.

${ }^{132}$ Tan Gazetesi, 20 Kasim 1938,

${ }^{133}$ Sonyel, a.g.m., s. 570

${ }^{134}$ Kurun Gazetesi, 20 Kasım 1938

${ }^{135}$ Son Posta Gazetesi, 19 Kasim 1938

${ }^{136}$ Ulus Gazetesi, 20 Kasım 1938; Tan Gazetesi, 20 Kasım 1938; Akşam Gazetesi, 20 Kasım 1938
} 
Emden, Yunanistan'dan Hydra gemileri vard $1 .{ }^{137}$

Yavuz zırhlısı, saat 19.30 'da İzmit Mayın İskelesi'ne yaklaştı. Cenaze, burada binlerce İzmitli tarafından karşılandı. İzmit'te de tören düzeni ve güvenlik önlemleri önceden alınmışt1. ${ }^{138}$ Yavuz zırhlısından alınan Atatürk'ün naaşı, tren istasyonuna götürüldü. Atatürk'ün tabutu, sağlığında yurt gezilerinde kullandığı beyaz renkli vagona konuldu. Atatürk'ün tabutunun konulduğu tren, saat 20.30 'da İzmit'ten ayrıld1. ${ }^{139}$ Tren, İzmit'ten sonra geçtiği bütün istasyonlarda yavaşlayarak Bilecik, Eskişehir, Polatlı ve Etimesgut'tan sonra Ankara'ya ulaştı. Hat boyunca, trenin geçtiği yerlerde halk, geç saate aldırmaksızın, kimi zaman ellerinde meşalelerle, treninin geçişini izlediler. Atatürk'ün naaşının taşıyan tren, 20 Kasım 1938 günü saat 10.03 'te Ankara garına ulaştı. ${ }^{140}$

\section{Ankara'da Cenaze Töreni}

Peronda, başta Cumhurbaşkanı İsmet İnönü, Meclis Başkanı Abdülhalik Renda, Genelkurmay Başkanı Fevzi Çakmak, bakanlar, milletvekilleri, komutanlar olmak üzere protokol üyeleri bulunuyordu. ${ }^{141}$ Cumhurbaşkanı İsmet İnönü, Meclis Başkanı Abdülhalik Renda ve Genelkurmay Başkanı Fevzi Çakmak tabutun bulunduğu vagona binerek sayg1 duruşunda bulundular. ${ }^{142}$ Tabut daha sonra vagondan alınarak bir top arabasına kondu. Tabutun bulunduğu top arabası, arkasından yürüyen Cumhurbaşkanı, Başbakan, Mareşal Fevzi Çakmak, milletvekilleri, mülki ve askeri erkân eşliğinde istasyondan Türkiye Büyük Millet Meclisi binasına geldi. Atatürk'ün tabutu daha önceden Bruno Taut'un hazırlamış olduğu katafalka konuldu. Başta Cumhurbaşkanı İnönü ve protokol katafalkın önünde saygı duruşunda bulundular. ${ }^{143} \mathrm{O}$ gün çekilen ve tabutun istasyondan alınıp Meclise götürüldüğünü gösteren fotoğraflarda, istasyon çevresinin boş olduğu görülmektedir. ${ }^{144}$ İstanbul'da meydana gelen izdihamın ardından Ankara'da güvenlik tedbirlerinin artırıldığı anlaşılmaktadır. Gazeteci Asım Us da, Ankara'da istasyon ile Türkiye Büyük Millet Meclisi arasına çıkan bütün yolların, askerler tarafından tutulduğunu, bu suretle halkın izdihamının önüne geçildiğini yazmaktadır. ${ }^{145}$

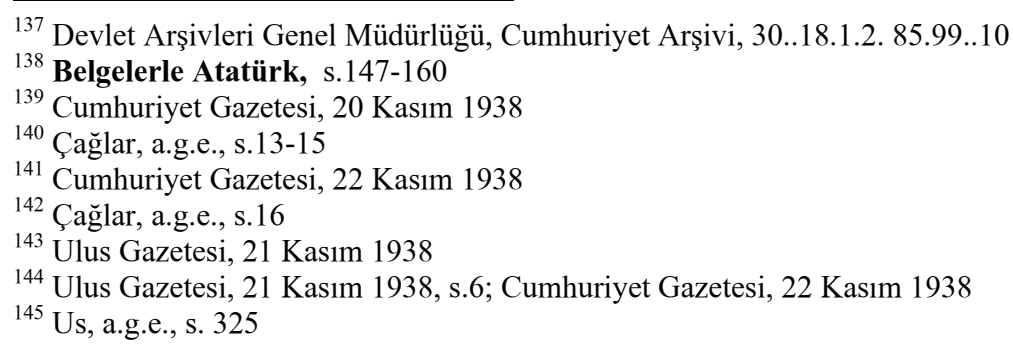


Meclisin önünde yer alan katafalkın çevresinde subaylar, 20 Kasım 1938 günü saat 10.30 'dan itibaren sayg1 nöbeti tuttular ve nöbet $21 \mathrm{Kas} 1 \mathrm{~m}$ 1938 günü törenin başlayacağı 09.00 saatine kadar devam etti. Sayg1 nöbeti, her rütbeden altı subayın yarım saat aralıklarla değiştiği 45 nöbet postası ile gerçekleşti. ${ }^{146}$

Saat 12.00 'den itibaren halkın katafalkın önünden sayg1 geçidi başladı ve gece yarısına kadar devam etti. Ankara'da da halk, İstanbul'daki gibi gözyaşları içinde katafalkın önünden geçti. ${ }^{147}$

Ertesi gün 21 Kasım 1938'de, Atatürk'ün tabutunun Etnografya müzesine konulduğu resmi devlet töreni düzenlendi. ${ }^{148}$ Cenaze töreni için çeşitli tedbirler alındı. Yalnızca törene davetlileri taşıyacak resmi görevli araçların trafiğe çıkmasına izin verildi. Halka Gençlik Parkı alanından töreni izleyebilmelerine müsaade edildi. Saat 08.00 'den sonra otobüs seferleri kaldırıldı. ${ }^{149}$

Saat 9.42'de Atatürk'ün tabutu, 12 milletvekili tarafindan katafalktan alınarak top arabasına yerleştirildi. Saat 10.07 'de, Türk ve Yabancı askeri birlikler top arabasının önünde sayg1 geçidi yaptılar. ${ }^{150}$ İlk önce mızraklı süvariler geçtiler, geçiş sırasında subaylar kilıçlarıyla tabutu selamlarken, erler mızraklarını aşağıya doğru çevirmiş ve başlarını tabuta doğru dönmüşlerdi. Onları sancaklarıyla topçular, muhafız alayı ve Harbiyeliler takip etti. Toplam dokuz ülke, cenaze törenine askeri birlikleri ile katıldı. Türk askeri birliklerin ardından Almanya, Bulgaristan, Fransa, İngiltere, İran, Romanya, Sovyetler Birliği Yugoslavya ve Yunanistan, askeri onur kıtaları bayrakları ve kılıçlarıyla Atatürk'ü selamladılar. ${ }^{151}$

Askeri birliklerin dışında on yedi devletin başkanları tarafından özel temsilciler gönderildi. Diğer ülkeleri büyükelçileri temsil etti. ${ }^{152}$ Nazi Almanya'sını Baron Von Neurath, İngiltere'yi Lord Birdwood, Fransa'y1 İçişleri Bakanı Albert Sarruat, İtalya'yı Baron Aloizi, Sovyetler Birliği'ni General Potemkin, Yugoslavya'yı Savunma Bakanı Nedic, Yunanistan'1 ise Başbakan Metaksas temsil ediyordu. ${ }^{153}$ Cenaze törenine katılan ülkelerden

\footnotetext{
${ }^{146}$ Belgelerle Atatürk, s.177-199

${ }^{147}$ Akşam Gazetesi, 21 Kasım 1938

148 Tan Gazetesi, 22 Kasım 1938; Akşam Gazetesi, 22 Kasım 1938; Ulus Gazetesi, 22 Kasım 1938

${ }^{149}$ Ulus Gazetesi, 22 Kasım 1938

${ }^{150}$ Çağlar, a.g.e.,, s. 17

151 Ulus Gazetesi, 22 Kasım 1938; Tan Gazetesi, 22 Kasım 1938; Akşam Gazetesi, 22 Kasım 1938

${ }^{152}$ Sonyel, a.g.m., s. 577

${ }^{153}$ Belgelerle Atatürk, s.209-218
} 
bir kısmı ile Türkiye daha on beş yıl önce savaştan çıkmıştı. Dahası cenaze törenine katılan ülkeler, bir yıl sonra başlayacak olan İkinci Dünya Savaşında düşman saflarda yer alacaklardı. Atatürk'ün cenaze töreni, farklı kamplarda yer alan ülkeleri bir araya getiren bir zemin oldu. Neue Zürcher Zeitung adlı İsviçre gazetesi, cenaze töreninde ortaya çıkan tabloyu şu şekilde tasvir etti:

“Atatürk'ün cenaze töreni, onun son zaferi oldu. Tabutunun önünde karşıtlarının hepsi sessiz kaldı. Türk ve Alman askerleri, tabutunun arkasında bir sirada yürüdüler; bir diğer sirada Stalin ve Hitler'in temsilcileri yan yanaydllar; hem Valencia hem de General Franco çiçek yollamışlardl. Tabutun önünde Faşistler, Demokratlar ve Komünistler eğildiler." 154

Askeri birliklerin geçidinin ardından saat 10.45 'de cenaze korteji, meclisin önünden Etnografya Müzesine Cumhurbaşkanlığı Bandosunun çaldığ ${ }_{1}$ Chopin'in matem marşı eşliğinde hareket etti. ${ }^{155}$ Cenaze kortejinin önünde Türk ve yabancı askeri birlikler ve bandolar yer alıyordu. Askeri birliklerin ardında 80 askerin çektiği ve yanında kılıçlarını çekmiş 12 generalin bulunduğu Atatürk'ün tabutunu taşıyan top arabası geliyordu. ${ }^{156}$ Top arabasını Atatürk'ün İstiklal Madalyasını taşıyan bir General takip ediyordu. Hemen ardından kız kardeşi Makbule Hanım ve eşi yürüyordu. ${ }^{157}$ Cumhurbaşkanlığı Genel Sekreteri Hasan Rıza Soyak ve Atatürk'ün yaverlerinin arkasında Cumhurbaşkanı İnönü, ağır adımlarla ilerliyordu. Cumhurbaşkanının ardından Türkiye Büyük Millet Meclisi Başkanı Abdülhalik Renda, Başbakan Celal Bayar, Genelkurmay Başkanı Fevzi Çakmak, yer alıyordu. Kortejde, daha sonra sırasıyla yabancı büyükelçiler, temsilciler, bakanlar, milletvekilleri, askeri ve mülki erkân bulunuyordu. ${ }^{158}$ Dönemin gazetelerine göre, cenaze kortejinin güzergâhında bulunan Gençlik Parkını halk doldurmuş; feryatlar, haykırışlar içinde gözyaşı döküyordu. ${ }^{159}$ Cenaze korteji, saat 13.10 'da Etnografya Müzesine ulaşt1. ${ }^{160}$ Başta Cumhurbaşkanı İnönü ve protokol yerlerini aldılar. Atatürk'ün tabutu top arabasından alındı. Türk askerlerinin omuzlarında Etnografya Müzesinin

${ }^{154}$ Orhan Koloğlu, Mazlum Milletler Devrimleri ve Türk Devrimi, Kaynak Yayınları, İstanbul, 2004, s.81

${ }^{155}$ Çağlar, a.g.e., s. 17

${ }^{156}$ Ulus Gazetesi, 22 Kasım 1938

${ }^{157}$ Kurun Gazetesi, 22 Kasim 1938

158 Akşam Gazetesi, 22 Kasım 1938; Ulus Gazetesi, 22 Kasım 1938; Belgelerle Atatürk, s. 168

159 Cumhuriyet Gazetesi, 22 Kasım 1938; Ulus Gazetesi, 22 Kasım 1938; Yeni Sabah Gazetesi 22 Kasim 1938

${ }^{160}$ Çağlar, a.g.e., s. 18 
girișinde yer alan beyaz mermerden kaidenin üzerine konuldu. 21 Kasım 1938 günü düzenlenen Atatürk'ün Naaşının Etnografya Müzesine Nakil Töreni, devlet adamlarının ve korteje katılanların veda geçişi ile son buldu. ${ }^{161}$

Cenaze töreninin ardından Atatürk'e veda konuşmasını, yeni "şef" Cumhurbaşkanı İnönü, yaptı. İnönü'nün Türk halkına seslendiği konuşması, 21 Kasım 1938 günü radyodan yayınland1. ${ }^{162}$

"Bütün ömrünü hizmetine vakfettiği sevgili milletinin ihtiram kollan üstünde Ulu Atatürk'ün fâni vücudu istirahat yerine tevdi edilmiştir. Hakikatte yattı̆g yer, Türk milletinin, O'nun için aşk ve iftiharla dolu kahraman ve vefalı göğsüdür" cümleleri ile başlayan konuşmada İnönü, Atatürk'ün ülkesine ve Türk milletine yaptığı hizmetlerden övgüyle söz etti. En kıymetli emanetinin "laik, milliyetçi, halkçı, inkılâpçı, devletçi cumhuriyet" olduğunu belirterek rejimin aynı ilkeler çerçevesinde yürüyeceğinin mesajını verdi. Kaybından sonra Türk Milletinin Atatürk'e gösterdiği sevgi ve saygıdan övgüyle söz ederek vatandaşlara teşekkür etti. Ayrıca, cenaze törenine katılan devletlere de Türk milleti adına şükranlarını bildirdi. Atatürk'e "Devletimizin banisi ve milletimizin fedakar, sadık hadimi; insanlık idealinin aşık ve mümtaz siması; Eşsiz kahraman Atatürk; Vatan sana minnettardır" diye seslenen İnönü, konuşmasını, "aziz hatıran sönmez meşale olarak ruhlarımızı daima ateşli ve uyanık tutacaktır” sözünü vererek tamamladi. ${ }^{163}$ İnönü’nün Atatürk'ün kaybından duyulan üzüntüyü ölçülü bir şekilde ifade eden konuşması, 22 Kasım 1938 tarihli gazetelerde yer ald1. ${ }^{164}$

\section{Sonuç}

Türkiye Cumhuriyeti kuruluşunun on beşinci yılını geride bıraktığı günlerde kurucusunu kaybetti. Ölümünün ardından on bir gün sonra Atatürk'ün naaşı, geçici kabir olarak belirlenen Etnografya Müzesine konuldu. Atatürk'ün ölüm haberinin ardından tüm ülkede, derin bir üzüntü yaşandığı, İstanbul ve Ankara'da düzenlenen törenlerde yas, bütün halleri ile gözlenmektedir. Bu yası ve üzüntüyü gözlemleyenlerden biri de İngiltere'nin Ankara Büyükelçisi Sir Percy Loraine oldu. Loraine, İngiltere’ye gönderdiği

\footnotetext{
${ }^{161}$ Ulus Gazetesi, 22 Kasim 1938

162 İnönü’nün radyo konuşma kaydının bir kısmı için bkz: Tunç Boran, (Yönetmen) 906 Rakımlı Tepe Belgesel Filmi, Emniyet Genel Müdürlüğü Foto Film Şube Müdürlüğü, 2003

${ }^{163}$ Devlet Arşivleri Genel Müdürlüğü, Cumhuriyet Arşivi 030.01..11.63.5; TBMM Zabıt Ceridesi, Devre V, İçtima 4, 21 Kasım 1938, Cilt 27, s..240

${ }_{164}$ Akşam Gazetesi, 22 Kasım 1938; Ulus Gazetesi, 22 Kasım 1938; Cumhuriyet Gazetesi, 22 Kasim 1938
} 
raporda, "Onun için gerçekten yas tutuluyor. Cenaze törenleri sırasında sıradan insanların samimi üzüntüsü kolayca anlaşıllyordu"165 demektedir. Halkın törenlere katılımı ve üzüntüsü, Atatürk'e duydukları sevgi ve saygıyı gösteriyordu.

Yetkililer tarafından törenlerin düzenlenme şekli ve alınacak güvenlik önlemleri ile ilgili pek çok genelge ve kararname yayınland $1 .{ }^{166}$ Genelge ve kararnamelerde, güvenlik tedbirlerinin üst düzeyde alındığ 1 dikkat çekmektedir. Devlet Başkanının cenaze töreni ile ilgili alınan güvenlik tedbirlerini doğal karşılamak gerekir. Ancak yine aynı genelge ve kararnamelerde, halkın törenlere katılımının sağlanmasıyla ilgili olarak herhangi bir düzenlemenin yapılmaması dikkat çekicidir. Bir başka deyişle belgelerden, halkın cenazeye katılımını sağlamak için özel bir çaba gösterilmediği anlaşılmaktadır. ${ }^{167}$ Katılım için özel bir çabanın gösterilmemesinin nedenleri, halkın zaten kendiliğinden yoğun katılımı ve hükümetin kontrolsüz kalabalıkların yaratması muhtemel güvenlik zafiyetinden çekinmesiydi. Cenaze namazının cami yerine Dolmabahçe Sarayında kılınması bu çekincenin ürünüdür. Özellikle Dolmabahçe Sarayında meydana gelen izdiham sonucu on bir kişinin ölümü, güvenlik tedbirlerinin daha da artırılmasına sebep olmuştur. İstanbul'da ve Ankara'da alınan tedbirler, halkın cenaze törenine katılmasını kolaylaştırmak yerine zorlaştırmıştır. Örneğin naaşın Ankara’ya gelmesi sırasında istasyon çevresi gibi alanlar halkın girişine kapatılmış, törenin düzenlendiği günlerde tramvay, otobüs, vapur seferleri kaldırılmış, özel araçların trafiğe çıkışı engellenmiştir. Alınan tüm bu güvenlik önlemlerine rağmen halk, Atatürk’e duyduğu sevgiyi göstermek için İstanbul, Ankara ve nakil sırasında naaşın geçtiği yerleşim birimlerinde yollara dökülmüştür.

Cenaze töreni herhangi bir aksaklık olmadan -sarayda meydana gelen izdiham dışında- önceden belirlenen program çerçevesinde düzenli ve disiplinli bir şekilde gerçekleştirildi. Başbakanlık, cenaze töreninde görev alan Dışişleri, İçişleri ve Milli Savunma Bakanlıkları çalışanlarına gösterdikleri gayretten ötürü takdirlerini bildirdi. ${ }^{168}$ Cumhuriyet Halk Partisi Genel Sekreterliği yayınladığı bildiri ile yas günlerinde gösterilen vakar ve sükût için halka ve yöneticilere teşekkür etti. ${ }^{169}$

\footnotetext{
${ }^{165}$ Sonyel, a.g.m., s. 585

166 Genelge ve kararnameler için Bkz: Belgelerle Atatürk, Milli Savunma Bakanlığı Yayınları, Ankara, 1999

${ }^{167}$ Hakan Uzun, "Liderine Ağlayan Bir Ulus: Atatürk'ün Ankara'daki Cenaze Töreni”, Atatürk Yolu, Ankara Üniversitesi Türk İnk1lâp Tarihi Enstitüsü Dergisi, S.43, Bahar 2009, s. 535

${ }_{168}$ Devlet Arşivleri Genel Müdürlüğü, Cumhuriyet Arşivi, 030-0-010-1-4-13

${ }^{169}$ Devlet Arşivleri Genel Müdürlüğü, Cumhuriyet Arşivi, 490..1.0.0-4.19..18
} 
Hükümet, İçişleri Bakanı Şükrü Kaya'nın Atatürk'ün ölümünden bir ay önce ifade ettiği gibi "Ĕger emri hak vaki olursa tedbir almak lazım. Teessür tabii umumidir. Fakat memleketi yeise düşürmemeli" ${ }^{170}$ prensibiyle hareket etmişti. Atatürk'ün ölümünden kaynaklanan üzüntünün, devletin sürekliliğine ve rejime olan inanca yönelik kuşkuya ve ümitsizliğe dönüşmemesi için tedbirler alınmıştı. Alınan tedbirler, Atatürk'ün kaybından dolay1 halkın duyduğu üzüntünün, rejime yönelik ümitsizliğe dönüşmemesini amaçlıyordu. ${ }^{171}$ Kısacası Türkiye, cenaze töreninde kurucusunu, önderini kaybetmenin üzüntüsünü yaşarken, cumhuriyetin ayakta kalacağı mesajını vermeye çalıştı.

${ }^{170}$ Us, a.g.e., s. 300

${ }^{171}$ Hakan Uzun, "Liderine Ağlayan Bir Ulus: Atatürk'ün Ankara'daki Cenaze Töreni”, Atatürk Yolu, Ankara Üniversitesi Türk İnkılâp Tarihi Enstitüsü Dergisi, S.43, Bahar 2009, s.547 


\section{KAYNAKÇA}

\section{Devlet Arşivleri Genel Müdürlüğü Cumhuriyet Arşivi}

Devlet Arşivleri Genel Müdürlüğü, Başbakanlığın 8 Ekim 1953 tarih ve 3057 sayılı yazısının eki.

Devlet Arşivleri Genel Müdürlüğü, Cumhuriyet Arşivi, 18.01.02.86.18.16

Devlet Arşivleri Genel Müdürlüğü, Cumhuriyet Arşivi 190.01.4.19.45. s.3

Devlet Arşivleri Genel Müdürlüğü, Cumhuriyet Arşivi, 030.18.12.116.42.7

Devlet Arşivleri Genel Müdürlüğü, Cumhuriyet Arşivi, 030.18.12.126.56.1

Devlet Arşivleri Genel Müdürlüğü, Cumhuriyet Arşivi, 030.0.010.1.4.13

Devlet Arşivleri Genel Müdürlüğü, Cumhuriyet Arşivi, 030.18.1.2. 85.99.10

Devlet Arşivleri Genel Müdürlüğü, Cumhuriyet Arşivi 030.01.11.63.5

Devlet Arşivleri Genel Müdürlüğü, Cumhuriyet Arşivi, 490.1.0.0-4.19.18

\section{Emniyet Genel Müdürlüğü Arşivi}

Emniyet Genel Müdürlüğü Personel Arşivi, A-1853 Numaralı Özlük Dosyası;

\section{TBMM Zabit Cerideleri}

TBMM Zabıt Ceridesi, Devre 5, İçtima 4, 11 Kasım 1938, Cilt 27.

TBMM Zabıt Ceridesi, Devre V, İçtima 4, 14 Kasım 1938, Cilt 27.

TBMM Zabıt Ceridesi, Devre V, İçtima 4, 21 Kasım 1938, Cilt 27

\section{Resmi Gazeteler}

Resmi Gazete, Sayı: 4059, 10 Kasım 1938.

Resmi Gazete, Say1: 4061, 12 Kasım 1938.

Resmi Gazete, Sayı: 4063, 15 Kasım 1938.

Resmi Gazete, Sayı: 4064, 16 Kasım 1938

Resmi Gazete, Sayı:4073, 1 Aralık 1938

Resmi Gazete, Sayı:4077, 6 Aralık 1938 


\section{Gazeteler}

Akşam Gazetesi

Cumhuriyet Gazetesi

Haber Akşam Postası

Kurun Gazetesi

Son Telgraf Gazetesi

Tan Gazetesi

Ulus Gazetesi

Yeni Sabah Gazetesi

\section{Dergiler}

Ayın Tarihi Dergisi

Yedigün Dergisi

\section{Kitaplar}

Altay, Fahrettin; On Yıl Savaş ve Sonrası, İnsel Yayınevi, İstanbul, 1970.

Aydemir, Şevket Süreyya; İkinci Adam, Cilt II, Remzi Kitabevi, İstanbul, 2000.

Belgelerle Atatürk; Milli Savunma Bakanlığı Yayınları, Ankara, 1999.

Boran, Tunç (Yönetmen); 906 Rakımlı Tepe Belgesel Filmi, Emniyet Genel Müdürlüğü Foto Film Şube Müdürlüğü, 2003.

Bozdağ, İsmet; Bir Çağın Perde Arkası Kervan Yayınları, İstanbul, 1972.

Çağlar, Behçet Kemal; Dolmabahçe'den Anıtkabir'e, Sel Yayınları, İstanbul, 1955.

Develioğlu, Ferit; Osmanlıca-Türkçe Ansiklopedik Lugat, Aydın Kitapevi, Ankara, 1990.

Egeli, Münir Hayri; Atatürk’ten Bilinmeyen Hatıralar, Yaşaroğlu Kitapçılık, İstanbul, 1959.

Eldem, Edhem; İstanbul'da Ölüm Osmanlı-İslam Kültüründe Ölüm ve Ritüelleri, Osmanlı Bankası Arşiv ve Araştırma Merkezi Yayınları, İstanbul, 2005.

Hariciye Vekâleti Protokol Dairesi, Atatürk'e yapılacak Cenaze Törenine Ait Esas Programıdır, Ankara, 1938. 
İnan, Arı; Tarihe Tanıklık Edenler, Çağdaş Yayınları, İstanbul, 1997.

Kınross, Lord; Atatürk Bir Milletin Yeniden Doğuşu, Altın Kitaplar Yayınevi, İstanbul, 1994.

Koloğlu, Orhan; Mazlum Milletler Devrimleri ve Türk Devrimi, Kaynak Yayınları, İstanbul, 2004.

Kocatürk, Utkan; Doğumundan Ölümüne Kadar Kaynakçalı Atatürk Günlüğü Atatürk Kültür Merkezi Yayını, Ankara, 1999.

Koçak, Cemil; Türkiye'de Milli Şef Dönemi (1938-1945) 1.Cilt, İletişim Yayınları, İstanbul, 2003.

Kutay, Cemal; Atatürk'ün Son Günleri, Boğaziçi Yayınları, İstanbul, 1981.

Sertel, Zekeriya; Hatırladıklarım, Gözlem Yayınları, İstanbul, 1977.

Öymen, Altan; Bir Dönem Bir Çocuk, Doğan Yayıncılık, İstanbul, 2003.

Ulusu, Nuri; Atatürk'ün Yanı Başında, Doğan Kitap, İstanbul, 2009.

Us, Asım; Asım Us'un Hatıra Notları, Vakit Matbaası, İstanbul, 1966.

Volkan, Vamık D.; Itzkowitz, Norman; Ölümsüz Atatürk, Bağlam Yayınları, İstanbul, 1998.

\section{Makaleler}

Atay, Neşet; "Gece yarısından sonra 50.000 kişi Büyük Ölüyü ziyaret için sıra bekliyordu," Ulus Gazetesi, 18 Kasım 1938

Barlas, Mehmet; “Celal Bayar'ın Anıları,” Günaydın Gazetesi, 9 Nisan 1976

Batur, Afife; "Katafalk; Ölümün Draması / Duygusal ve Zarif" Atatürk İçin Düşünmek, İstanbul Teknik Üniversitesi Yayını, İstanbul, 1998.

Deniz, Ümit; "Büyük Atanın Tabutu Nasıl Açıldı," Milliyet Gazetesi, 2 Temmuz 1955.

Doğaner, Yasemin; "Millet Liderini Uğurluyor," Atatürk Üniversitesi Atatürk Dergisi (Journal of Ataturk), c..IV, Sayı:2, Ocak 2005

Dörner, Friedrich Karl; “Atatürk'e Veda," Mustafa Kemal Atatürk 1881-1938, Çev: Nuran Özyer, Ankara, 1997.

Esin, Seyfullah; “Atatürk'ün Cenaze Merasimine Dair Hatıralar”, Türk Kültürü, Yıl: XIV, S.157 Atatürk Sayıs1

Gezgin, Hakk1 Süha; “Onun Huzurunda” Kurun Gazetesi, 18 Kasım 1938.

Güntekin, Reşat Nuri; “Celal Bayar’ın Gözyaşları,” Tan Gazetesi, 20 Kasım 1938 
Koçu, Reşad Ekrem; "Çelenk," İstanbul Ansiklopedisi, Neşriyat Kolektif Şirketi, Cilt:7, İstanbul, 1965.

Kutay, Cemal; "Büyük Ölünün Tabutu İstanbul'dan Ayrılırken.” Ulus, 21, 11, 1938.

Mutlu, Kamile Şevki; “Atatürk'ün Anıt-Kabre Naklinden Bir Hatıra” (14 Mart 1964 Tıp Dergisinden Tipkı Basım) Bilim ve Teknik Dergisi, Sayı:329, Nisan 1995.

Nicolai, Bernd; "Bruno Taut'un Akademi Reformu ve Türkiye için Yeni Bir Mimariye Uzanan Yol” Atatürk İçin Düşünmek, İstanbul Teknik Üniversitesi Yayını, İstanbul, 1998.

Sevengil, Refik Ahmet; “Atatürk'ün Cenaze Törenine Dair Hatıralar," İnkılâp Gençliği, Yıl:1, S.5, İstanbul, 1952

Sonyel, Salahi; "İngiliz Belgelerinin Işığı Altında Atatürk'ün Son Günleri," Belleten Cilt XXV Say1 140, Türk Tarih Kurumu, Ankara, Ekim 1971.

Tınal, Melih; Atatürk'ün İzmir Ziyaretleri ve Vefatının İzmir'deki Yankıları, ÇTTAD, VII/16-17, (2008/Bahar-Güz)

Toksoy, Nurcan; “Avrupa Gazetelerinde Atatürk'ün Ölümüyle İlgili Olarak Ortaya Çıkan Haber ve Yorumların Türk Basınına Yansıması," Ankara Üniversitesi Türk İnkılap Tarihi Enstitüsü Atatürk Yolu Dergisi, S. 37-38 Mayıs-Kasım 2006

Uzun, Hakan; "Liderine Ağlayan Bir Ulus: Atatürk'ün Ankara'daki Cenaze Töreni”, Atatürk Yolu, Ankara Üniversitesi Türk İnkılâp Tarihi Enstitüsü Dergisi, S.43, Bahar 2009 